\title{
Peptidomimetic polyurethanes disrupt surface established bacterial biofilms and prevent biofilm formation
}

\author{
Apoorva Vishwakarma ${ }^{1}$, Francis Dang ${ }^{1}$, Allison Ferrell ${ }^{1}$, Hazel A. Barton ${ }^{2}$, \\ Abraham Joy ${ }^{*}$
}

${ }^{1}$ School of Polymer Science and Polymer Engineering, ${ }^{2}$ Department of Biology, The University of Akron, Akron, OH 44325, USA

Antibiofilm| Biofilm disrupting| Bacteria-surface interactions| Bacterial adhesion| Biofilm|

\begin{abstract}
Over $80 \%$ of all chronic bacterial infections in humans are associated with biofilms, which are surface-associated bacterial communities encased within a secreted exopolysaccharide matrix that can provide resistance to environmental and chemical insults. Biofilm formation triggers broad adaptive changes in the bacteria, allowing them to be almost a thousand-fold more resistant to conventional antibiotic treatments and host immune responses. The failure of antibiotics to eliminate biofilms leads to persistent chronic infections and can promote the development of antibiotic-resistant strains. Therefore, there is an urgent need to develop agents that effectively prevent biofilm formation and eradicate established biofilms. Herein, we present water-soluble synthetic peptidomimetic polyurethanes that can disrupt surface established biofilms of Pseudomonas aeruginosa, Staphylococcus aureus, and Escherichia coli, all of which show tolerance to the conventional antibiotics polymyxin B and ciprofloxacin. Furthermore, these polyurethanes prevent bacterial attachment and stimulate bacterial surface motility to inhibit biofilm formation of both Gram-positive and Gram-negative bacteria at sub-inhibitory concentrations, without being toxic to mammalian cells. Our results show that these polyurethanes show promise as a platform for the development of therapeutics that target biofilms and modulate surface interactions of bacteria for the treatment of chronic biofilm-associated infections and as antibiofilm agents.
\end{abstract}

\section{INTRODUCTION}

In nature, bacteria generally exist as part of highly organized, surface-attached communities of cells protected by a hydrated, self-secreted polymeric matrix known as biofilms. ${ }^{1}$ According to the US National Institutes of Health (NIH), biofilms are associated with approximately $65 \%$ of all microbial infections and over $80 \%$ of all chronic infections in humans, which include catheter and device-associated infections, endocarditis, cystic fibrosis, and chronic wounds among others. ${ }^{2-3}$ These infections are hard to treat and often recurrent, leading to elevated patient morbidity and mortality, thus posing a significant healthcare burden. ${ }^{4-5}$ The estimated annual direct cost of biofilm-associated infections in the US is $\$ 94$ billion with almost 500,000 deaths annually. ${ }^{6}$ The current standard of care for these chronic infections is long-term antibiotic treatment with multiple antibiotics. ${ }^{7}$ However, treatment of these infections is extremely challenging because within a biofilm bacteria are highly tolerant to conventional antibiotics and biocides and can also evade host immune responses. ${ }^{2,8-10}$ The extended use of antibiotics to treat such infections also increases the development of antibiotic-resistant strains, further aggravating the problem of bacterial persistence in these infections. ${ }^{11-12}$ Thus there is an urgent need to develop agents that can address the threat posed by biofilms in healthcare settings.

While significant research has been dedicated to preventing biofilm formation on surfaces, ${ }^{13}$ removing surface established biofilms remains a challenge. Antibiofilm strategies involving debridement, ${ }^{14-15}$ bacterial signaling inhibitors, ${ }^{16-18}$ EPS degrading agents, ${ }^{19-21}$ bacteriophages, ${ }^{22}$ combinatorial antibiotic therapies, ${ }^{23-24}$ and antimicrobial peptides ${ }^{25-26}$ and polymers, ${ }^{27-30}$ are currently being investigated. Of these, antimicrobial peptides and polymers have emerged as promising candidates, due to their broad-spectrum antimicrobial activity, low incidence of 
resistance development, and the ability to kill stationary phase 'persister' cells through membrane-active mode of action. Host defense antimicrobial peptides like LL-37 and lactoferrin, ${ }^{31-32}$ and synthetic peptides reported by Hancock and coworkers ${ }^{33-35}$ have been shown to disperse mature biofilms and influence bacterial social behaviors like quorum sensing, swarming and twitching motility. However, peptides inherently suffer from high susceptibility to proteolytic degradation, $\mathrm{pH}$ sensitivity, and undesired serum-protein interactions, thus making their clinical translation difficult. ${ }^{36}$ Synthetic peptidomimetic polymers have been shown to overcome some of these challenges while having comparable antimicrobial activities. ${ }^{37}$ For instance, Haldar and coworkers have developed membrane active polymers and antimicrobial compounds that can kill biofilm bacteria at concentrations $\geq 10 \times$ MIC (Minimum inhibitory concentration of planktonic bacteria). ${ }^{38-39}$ Antimicrobial polycarbonates reported by Yang and coworkers have been shown to kill planktonic bacteria and disrupt biofilms of S. aureus and E. coli at concentrations of $8 \times$ MIC $(\sim 500 \mu \mathrm{g} / \mathrm{mL})$ or above. ${ }^{29}$ Boyer and coworkers have incorporated nitric oxide as a biofilm dispersing agent into antimicrobial polyacrylates to show synergism in clearance of immature (grown for 6.5 h) P. aeruginosa biofilms at concentrations as low as $16 \mu \mathrm{g} / \mathrm{mL} .{ }^{28,40}$ However, the focus in the examples listed above was on designing polymers that can kill multidrug-resistant planktonic bacteria, and not on disrupting biofilms. The few antimicrobial polymers that have been reported to disrupt biofilms are either active against immature biofilms, ${ }^{28,40}$ or are needed in high concentrations $(\geq 8 \times \mathrm{MIC})$ to disrupt established biofilms, ${ }^{29,}{ }^{38-39}$ which can potentially lead to high host-cell toxicity due to their membrane-active nature. ${ }^{41}$ The mechanism of antibiofilm action of these polymers, which may be different from the antimicrobial mechanism of action, has also not been investigated in detail. ${ }^{25}$

We have previously reported a library of synthetic peptidomimetic antimicrobial polymers with tunable selectivity and low cytotoxicity. ${ }^{42-45}$ In this study, we focused on variants of these polymers with activity against biofilms and systematically explored the mechanisms behind their antibiofilm characteristics through structureproperty relationships. Inspired by natural ${ }^{31-32}$ and synthetic ${ }^{33-35,46}$ antibiofilm peptides reported in the literature, we designed polyurethanes using our pendant-functionalized, amino acid mimetic monomer library to understand how individual amino acid mimetic units would influence the activity of the polyurethane against biofilms, and the surface interactions of bacteria preceding biofilm formation. The polyurethanes were designed to have arginine-mimetic or lysine-mimetic groups as their cationic groups, while the hydrophobicity was modulated by using mimics of phenylalanine and alanine as pendant groups to impart amphiphilicity to the polymer. Our data suggest that differences in the polyurethane pendant functional group significantly alter the surface-associated bacterial behavior like attachment, surface motility, and biofilm formation. 


\section{RESULTS AND DISCUSSION}

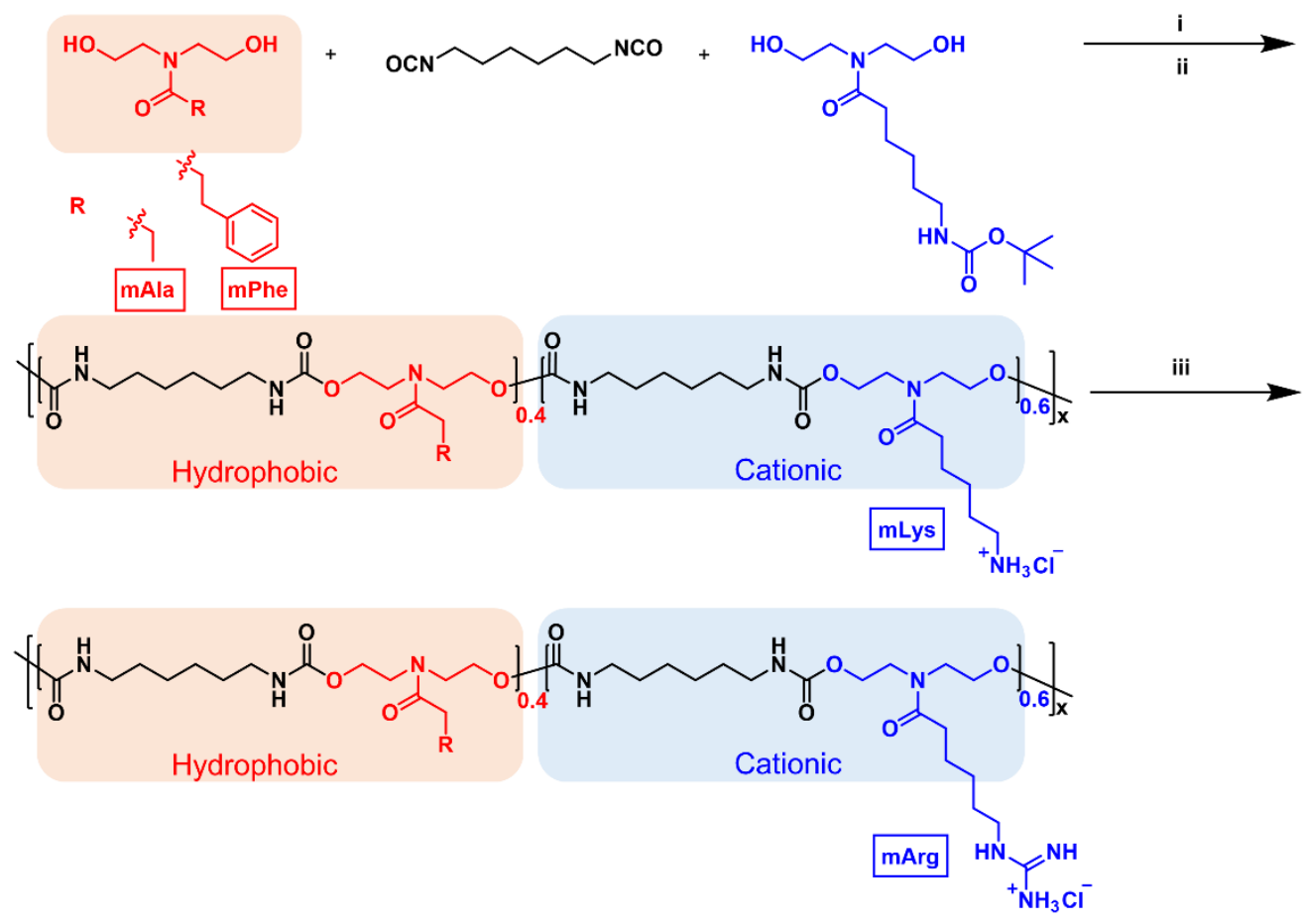

Figure 1. Synthetic scheme of the peptidomimetic polyurethanes with mLys and mArg as the charged pendant groups and mPhe and mAla as the hydrophobic pendant groups. The polymers were synthesized with charge to hydrophobicity ratio of 60/40. Reagents and reaction conditions: (i) Tin (II) octoate, $\mathrm{CH}_{2} \mathrm{Cl}_{2}$, at room temperature, $12 \mathrm{~h}$; (ii) $4 \mathrm{~N} \mathrm{HCl}$ in dioxane, $\mathrm{CH}_{2} \mathrm{Cl}_{2}$, at room temperature, 45 min (iii) 1H-Pyrazole-1-carboxamidine hydrochloride, triethylamine, DMF at $60{ }^{\circ} \mathrm{C}, 6 \mathrm{~h}$.

\section{Polyurethane design and synthesis}

The polyurethanes reported in this work were designed to mimic synthetic antibiofilm peptides. ${ }^{26,33-35}$ While there is no design consensus as to which structural features contribute to the mechanism of action against biofilms, antibiofilm peptides reported in the literature are charged, amphiphilic molecules having $40-50 \%$ cationic residues, along with some highly hydrophobic residues present in a short peptide sequence. Based on that, we chose 60/40 ratio of charge/hydrophobicity to mimic structural aspects of these peptides while ensuring polymer solubility in various growth media. The polyurethanes were synthesized using a simple, one-pot step-growth polymerization of $N$-functionalized diethanolamide monomers with hexamethylene diisocyanate using methods previously optimized in our lab, and detailed in the experimental section (Figure 1). ${ }^{43-44}$ The monomers were synthesized as reported previously and were designed to be structural mimics of lysine (mLys), alanine (mAla), and phenylalanine (mPhe) ${ }^{44,}{ }^{48}$ To mimic arginine (mArg), the mLys units were guanylated after the polymerization using $1 \mathrm{H}$-Pyrazole-1-carboxamidine hydrochloride in the presence of triethylamine in DMF. The bocdeprotection and guanylation were confirmed using ${ }^{1} \mathrm{H}$ NMR of the obtained polymers (Figure S1 B). The copolymer ratio of 60/40 charged/hydrophobic units was achieved by appropriate feed ratio of the co-monomers and the composition of the synthesized polymer was confirmed by NMR (Figure S1 A). Table 1 shows that the molar masses $\left(\mathrm{M}_{\mathrm{n}}\right)$ of the polyurethanes range between $9-10 \mathrm{~kg} / \mathrm{mol}$. Since the molar mass and hydrophobicity of the polymer directly influence its toxicity towards mammalian cells, ${ }^{43-44}$ we minimized the cytotoxicity of the designed polymers by synthesizing polymers with lower molecular weights to compensate for the addition of hydrophobic pendant groups. 
Inhibition of biofilm formation and disruption of surface established biofilms

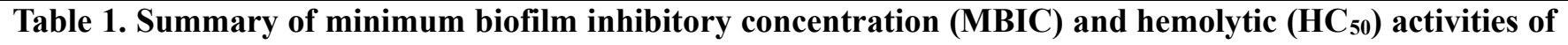
polymers and antibiotics against $P$. aeruginosa, $S$. aureus and $E$. coli

\begin{tabular}{llllll}
\hline $\begin{array}{l}\text { Polymer or antibi- } \\
\text { otic }\end{array}$ & $\begin{array}{l}\text { MBIC }(\mu \mathrm{g} / \mathrm{mL}) \\
(\text { P. aeruginosa })\end{array}$ & $\begin{array}{l}\mathrm{MBIC}(\mu \mathrm{g} / \mathrm{mL}) \\
(\text { S. aureus })\end{array}$ & $\begin{array}{l}\mathrm{MBIC}(\mu \mathrm{g} / \mathrm{mL}) \\
(\text { E. coli })\end{array}$ & $\mathrm{HC}_{50}(\mu \mathrm{g} / \mathrm{mL})$ & $\mathrm{M}_{\mathrm{n}}(\mathrm{g} / \mathrm{mol})[\mathrm{Ð}]$ \\
\hline mLys/mPhe & 8 & 8 & 2 & 260.5 & $10476[1.77]$ \\
$\mathrm{mLys} / \mathrm{mAla}$ & 8 & 16 & 4 & $>1250$ & $9326[1.72]$ \\
$\mathrm{mArg} / \mathrm{mPhe}$ & 4 & 4 & 2 & 197.5 & $\sim 10476[1.77]^{\mathrm{a}}$ \\
$\mathrm{mArg} / \mathrm{mAla}$ & 4 & 4 & 2 & 551.6 & $\sim 9326[1.72]^{\mathrm{a}}$ \\
Polymyxin B & 0.8 & 625 & 0.8 & - & 1301.56 \\
Ciprofloxacin & 0.2 & 0.08 & 0.09 & - & 733.93 \\
\hline
\end{tabular}

${ }^{a} \mathrm{mArg}$ polymers were functionalized post-polymerization from their mLys counterparts.

Table 2. Summary of minimum inhibitory concentration (MIC) of polymers and antibiotic controls against $P$. aeruginosa, $S$. aureus, and $E$. coli

\begin{tabular}{|c|c|c|c|c|c|c|c|}
\hline \multirow{2}{*}{$\begin{array}{l}\text { Polymer or } \\
\text { antibiotic }\end{array}$} & \multicolumn{3}{|c|}{ MIC in MHB $(\mu \mathrm{g} / \mathrm{mL})$} & \multicolumn{3}{|c|}{$\mathrm{MIC}$ in BM2 MM $(\mu \mathrm{g} / \mathrm{mL})$} & \multirow{2}{*}{$\begin{array}{l}\text { MIC in LB } \\
(\mu \mathrm{g} / \mathrm{mL}) \\
(P . \text { aerugino } \\
s a)\end{array}$} \\
\hline & (P. aeruginosa) & (S. aureus) & $\begin{array}{l}(E . \\
\text { coli) }\end{array}$ & (P. aeruginosa) & (S. aureus) & $\begin{array}{l}(E . \\
\text { coli })\end{array}$ & \\
\hline mLys/mPhe & $>250$ & $>250$ & $>250$ & 8 & 64 & 2 & $>250$ \\
\hline mLys/mAla & $>250$ & $>250$ & $>250$ & 16 & $>250$ & 16 & $>250$ \\
\hline $\mathrm{mArg} / \mathrm{mPhe}$ & $>250$ & $>250$ & 125 & 4 & 4 & 2 & $>250$ \\
\hline $\mathrm{mArg} / \mathrm{mAla}$ & $>250$ & $>250$ & $>250$ & 4 & 4 & 4 & $>250$ \\
\hline Polymyxin B & 0.8 & 625 & 0.4 & 0.8 & 625 & 0.4 & 0.8 \\
\hline Ciprofloxacin & 1.56 & 0.08 & 0.4 & 0.2 & 0.08 & 0.1 & 1.56 \\
\hline
\end{tabular}

We first tested the ability of these polymers to prevent biofilm formation on abiotic surfaces against three common, biofilm-forming opportunistic bacterial pathogens, viz., P. aeruginosa, S. aureus, and E. coli, in BM2 minimal medium supplemented with $0.4 \%$ glucose and $0.5 \%$ casamino acids (which supports biofilm formation of all three species studied). The MBIC experiment as described in the experimental section of the supporting information, was performed by growing the biofilms in increasing polymer concentration, with polymyxin B sulfate and ciprofloxacin as antibiotic controls. All polymer compositions tested showed broad-spectrum biofilm inhibition at low concentrations for P. aeruginosa $(\mathrm{MBIC}=4-8 \mu \mathrm{g} / \mathrm{mL}$; Table 1$), S$. aureus $(\mathrm{MBIC}=4-16$ $\mu \mathrm{g} / \mathrm{mL}$; Table 1$)$ and E. coli $(\mathrm{MBIC}=2-4 \mu \mathrm{g} / \mathrm{mL}$; Table 1$)$. While the pendant group hydrophobicity did not have a significant impact on the MBIC values, there was a notable influence of the cationic group on biofilm inhibition, with $\mathrm{mArg}$ containing polyurethanes. ( $\mathrm{mArg} / \mathrm{mAla}$ and $\mathrm{mArg} / \mathrm{mPhe}$ ) having a biofilm inhibitory effect at $2-$ $4 \mu \mathrm{g} / \mathrm{mL}$ for all tested species of bacteria compared to their mLys counterparts.

Since these polymers share design features with antimicrobial polymers, we also evaluated their antimicrobial activity against planktonic bacteria using the modified broth microdilution method. ${ }^{42-44}$ The MIC of the polymers was determined in MHB, LB, and BM2 minimal medium. As depicted in Table 2 the polymers showed no inhibitory activity against $P$. aeruginosa, $S$. aureus, or E. coli in MHB or LB until $250 \mu \mathrm{g} / \mathrm{mL}$ above which they could not be tested due to their poor solubility in LB and MHB. However, in BM2 minimal media, the polymers inhibited the growth of all three bacteria. mLys polymers had selective activity towards Gram-negative pathogens $P$. aeruginosa and E. coli (MIC $\sim 2-16 \mu \mathrm{g} / \mathrm{mL}$ ) while having high inhibitory concentrations or no activity towards Gram-positive $S$. aureus (MIC $=64 \mu \mathrm{g} / \mathrm{mL}$ for $\mathrm{mLys} / \mathrm{mPhe}$ and $\mathrm{MIC}>250 \mu \mathrm{g} / \mathrm{mL}$ for $\mathrm{mLys} / \mathrm{mAla}$ ), while $\mathrm{mArg}$ 
polymers had a broad-spectrum activity with MIC $\sim 2-4 \mu \mathrm{g} / \mathrm{mL}$ for both Gram-positive and Gram-negative bacteria. This trend in the MIC corroborates our previous reports on a similar polyurethane platform. ${ }^{43-44}$ Interestingly, the type of growth media did not affect the inhibitory activity of lipopeptide polymyxin B (MIC $=0.8 \mu \mathrm{g} / \mathrm{mL}$ against $P$. aeruginosa and $0.4 \mu \mathrm{g} / \mathrm{mL}$ against $E$. coli), while ciprofloxacin had higher MIC values in LB and MHB than in BM2 minimal media.

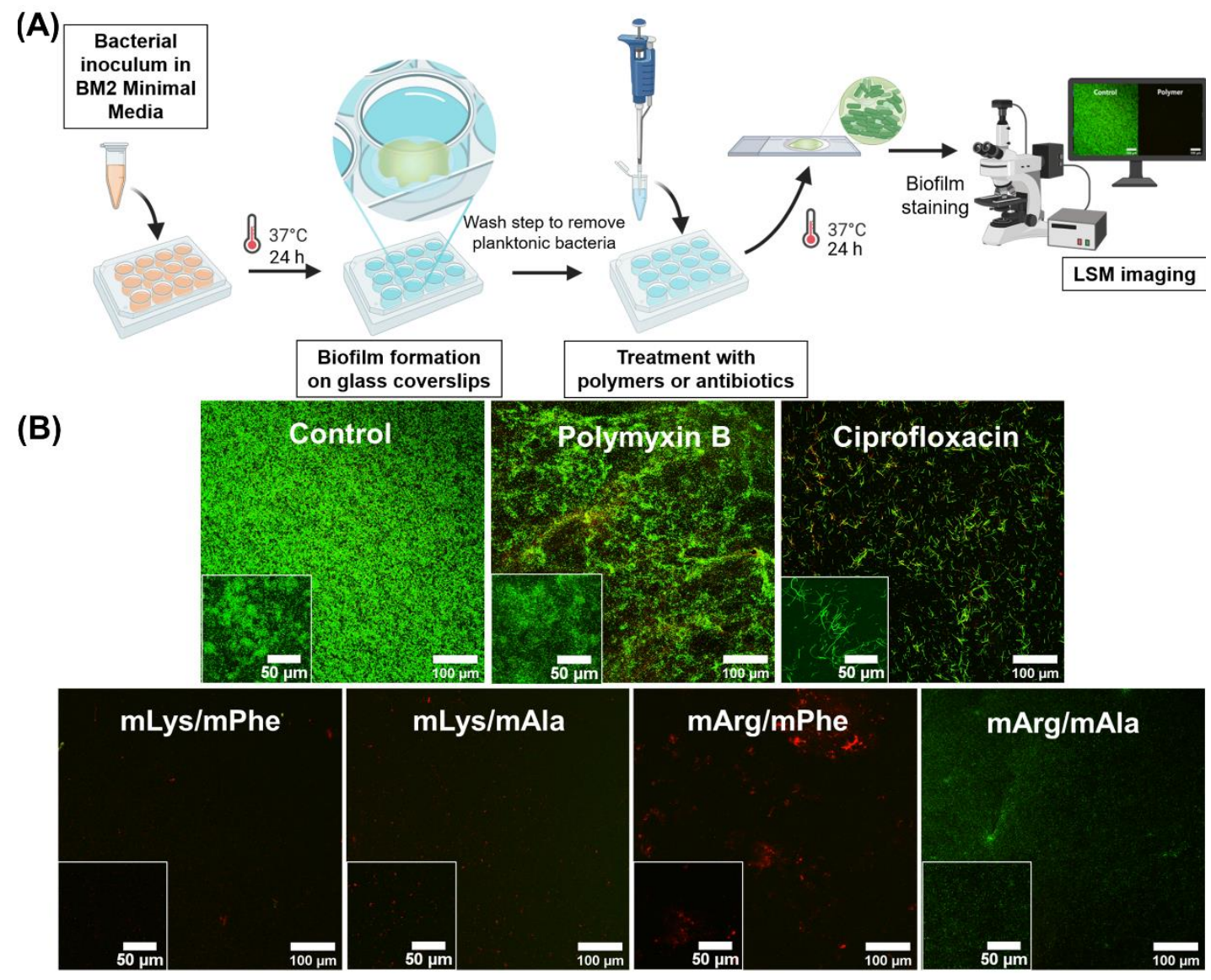

Figure 2. (A) Experimental workflow of biofilm disruption assay (B) Fluorescence confocal micrographs of preformed P. aeruginosa biofilms treated with polymyxin $\mathrm{B}(4 \mu \mathrm{g} / \mathrm{mL} \sim 5 \times \mathrm{MBIC})$, ciprofloxacin $(1 \mu \mathrm{g} / \mathrm{mL} \sim 10 \times \mathrm{MBIC})$, and polyurethanes $(16-32 \mu \mathrm{g} / \mathrm{mL}$, $\sim 4 \times$ MBIC). Permeabilized cells, indicative of cell death, stain red. Intact cells, indicative of viable cells, stain green. Scale bar represents $100 \mu \mathrm{m}$. (50 $\mu \mathrm{m}$ for the inset images).

While the prevention of biofilm formation on surfaces is desirable and has been a major topic of research, the removal of surface established biofilms remains a challenge. ${ }^{49} P$. aeruginosa is a notorious biofilm-forming pathogen, implicated in several biofilm-associated debilitating infections. Under laboratory conditions, $P$. aeruginosa readily forms dense biofilms within $24 \mathrm{~h}$ of inoculation in BM2 minimal media. We exposed these surfaceestablished biofilms to our polymers and antibiotics at different concentrations and imaged them using a confocal microscope. As depicted in Figure $2 \mathrm{~B}$, the antibiotics polymyxin B (at $4 \mu \mathrm{g} / \mathrm{mL}, \sim 5 \times \mathrm{MIC}$ ) and ciprofloxacin (at $4 \mu \mathrm{g} / \mathrm{mL}, \sim 10 \times \mathrm{MIC}$ ) were unable to completely disrupt $P$. aeruginosa biofilms. Furthermore, ciprofloxacin exposure led to the formation of elongated, filamentous cells that have been implicated in the development of antibiotic resistance. ${ }^{9,50-51}$ These observations support what has been well established in literature: while antibiotics are very effective in killing planktonic cells, they fail to adequately target and destroy biofilms, leading to persistent and chronic infections. ${ }^{11}$ However, the polymers $\mathrm{mLys} / \mathrm{mPhe}$ and $\mathrm{mLys} / \mathrm{mAla}$ were able to disrupt the $P$. aeruginosa biofilms, including cell debris, from the surface at $32 \mu \mathrm{g} / \mathrm{mL}(\sim 4 \times \mathrm{MBIC})$. Biofilm treated with $\mathrm{mArg} / \mathrm{mPhe}$ at $16 \mu \mathrm{g} / \mathrm{mL}(\sim 4 \times \mathrm{MBIC})$ had bacterial aggregates that stained red, indicative of permeabilized cells while $\mathrm{mArg} / \mathrm{mAla}$ treated biofilm had sparsely distributed viable cells attached to the surface (Figure 2 B). Higher concentrations of the polymers lead to the complete disruption of surface biofilms. The polymers were also able to disrupt $S$. aureus and E. coli biofilms as depicted in Figure S2, indicating broad-spectrum action against biofilms. Our results show that while these polyurethanes do not have significant growth inhibitory activity against 
planktonic $P$. aeruginosa, $S$. aureus, or E. coli, they can inhibit their biofilm formation as well as disrupt established biofilms.

\section{Influence on bacterial adhesion and surface motility}

(A)
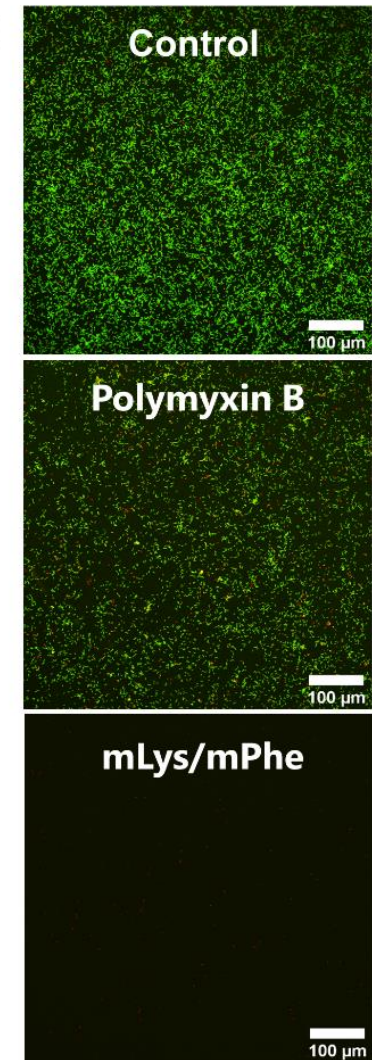
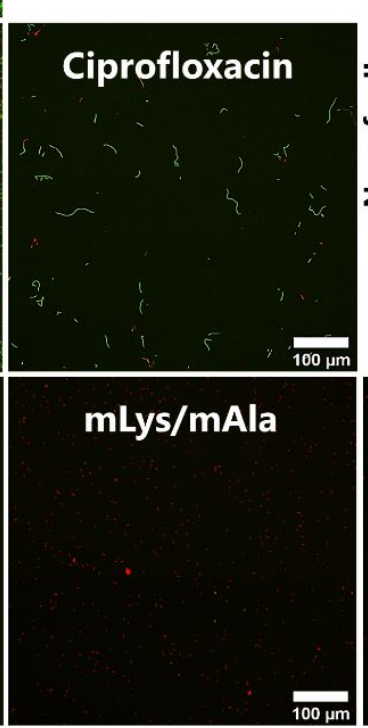

(B)
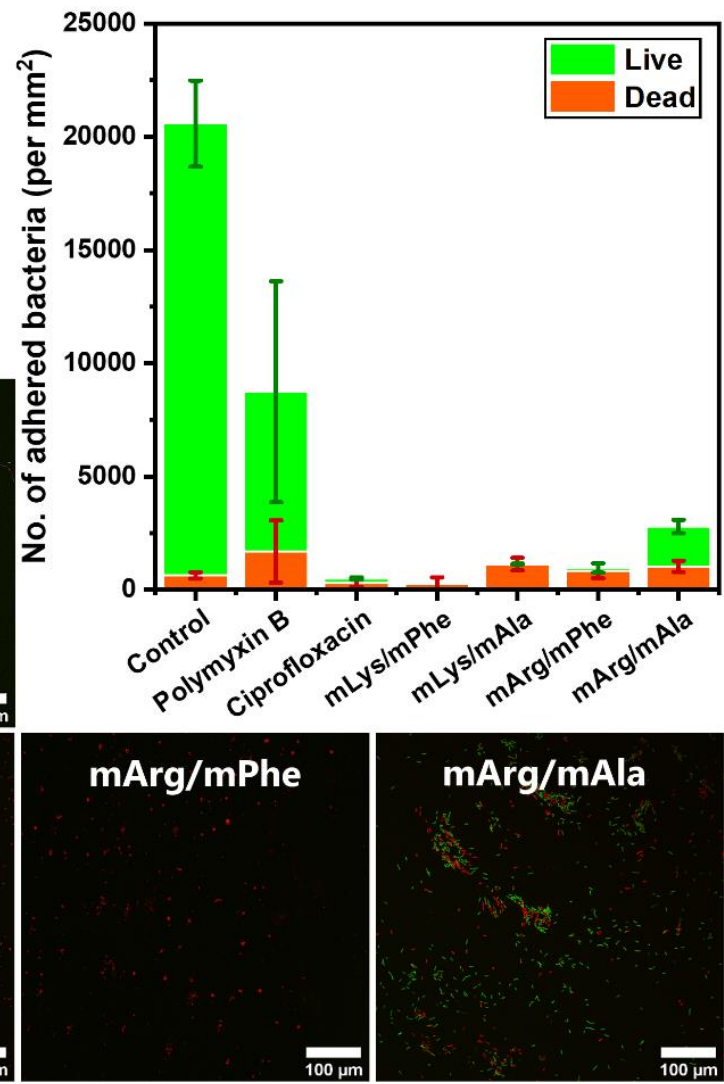

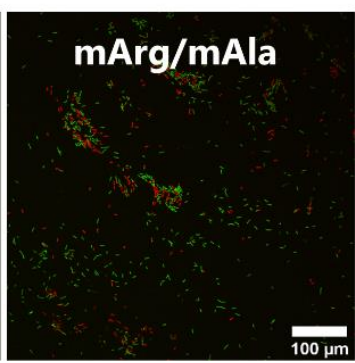

Figure 3. (A) Live/dead fluorescence images of $P$. aeruginosa cells attached to glass coverslips in presence of control, antibiotics, and polymers. (B) Graphical representation of attachment of $P$. aeruginosa on glass in presence of sub-MBIC antibiotics and polymers (mLys $/ \mathrm{mPhe}$ and mLys/mAla are at $2 \mu \mathrm{g} / \mathrm{mL}$ and $\mathrm{mArg} / \mathrm{mPhe}$ and $\mathrm{mArg} / \mathrm{mAla}$ are at $1 \mu \mathrm{g} / \mathrm{mL}(0.25 \times$ MBIC). Polymyxin B is at 0.5 $\mu \mathrm{g} / \mathrm{mL}$ and ciprofloxacin at $0.1 \mu \mathrm{g} / \mathrm{mL}(0.5 \times \mathrm{MBIC})$. The cell counts per $\mathrm{mm}^{2}$ area are shown as mean \pm SD. Green bars in the graph correspond to number of bacteria fluorescing green, indicative of intact cells, while red bars correspond to bacteria fluorescing red, indicating permeabilized cells.

Biofilm formation is a dynamic, multistep process that begins with surface detection, followed by attachment of the bacteria to the surface. ${ }^{49}$ Filamentous protein structures such as pili and flagella are employed by the bacteria for surface detection, translocation, and attachment. ${ }^{8}$ We hypothesized that the ability of the polymers to inhibit biofilm formation and disrupt established biofilms of a broad spectrum of bacteria could be due to the influence of the polymers on these surface interactions. To study surface-attachment, $P$. aeruginosa PAO1 cells were allowed to adhere to a glass substrate in BM2 minimal media containing known concentrations of polymers or antibiotics. As depicted in Figure $3 \mathrm{~B}, P$. aeruginosa in BM2 minimal media rapidly attached to the glass surface within $3 \mathrm{~h}$, reaching approximately $2 \times 10^{4}$ cells $/ \mathrm{mm}^{2}$. In presence of $0.5 \mu \mathrm{g} / \mathrm{mL}$ (about $0.5 \times \mathrm{MBIC}$ ) of polymyxin $\mathrm{B}$, the number of attached bacteria reduced to approximately $1 \times 10^{4} \mathrm{cell} / \mathrm{s} / \mathrm{mm}^{2}$, with a significant number of viable cells that fluoresced green. Bacteria in the presence of sub-inhibitory concentrations of ciprofloxacin $(0.1$ $\mu \mathrm{g} / \mathrm{mL}, 0.5 \times$ MBIC) also had viable cells that were almost $100 \times$ elongated and appeared as filaments. For Gramnegative bacteria, filamentation in the presence of sub-inhibitory concentrations of ciprofloxacin has been reported in the literature to occur via the SOS pathway, a state of rapid DNA repair and mutagenesis, implicated in the development of antibiotic resistance. ${ }^{50}$ The elongation of attached cells was not observed in the case of polymers or polymyxin B (Figure $3 \mathrm{~A}$ ). On the other hand, the polymers were able to reduce the attachment of bacteria to only a few hundred cells $/ \mathrm{mm}^{2}$ at as low as $0.25 \times \mathrm{MBIC}(\sim 1-2 \mu \mathrm{g} / \mathrm{mL})$. Among the polymers, $\mathrm{mLys} / \mathrm{mPhe}$ at 2 $\mu \mathrm{g} / \mathrm{mL}$ had the least number of surface-attached cells, all of which fluoresced red, indicating non-viability. $\mathrm{mArg} / \mathrm{mAla}$ at $1 \mu \mathrm{g} / \mathrm{mL}$ had the most surface-attached cells, with $\sim 1 \times 10^{3}$ cells $/ \mathrm{mm}^{2}$, having a mix of both viable 
and non-viable cells. At concentrations higher than $2 \mu \mathrm{g} / \mathrm{mL}$, no cells were observed to attach to the glass surface in the presence of polymers within the $3 \mathrm{~h}$ period of study. At concentrations higher than $2 \mu \mathrm{g} / \mathrm{mL}$ bacteria did not attach to the surface and hence biofilm formation was prevented, which could explain why the polymers inhibit biofilm formation at concentrations of $4-8 \mu \mathrm{g} / \mathrm{mL}$.

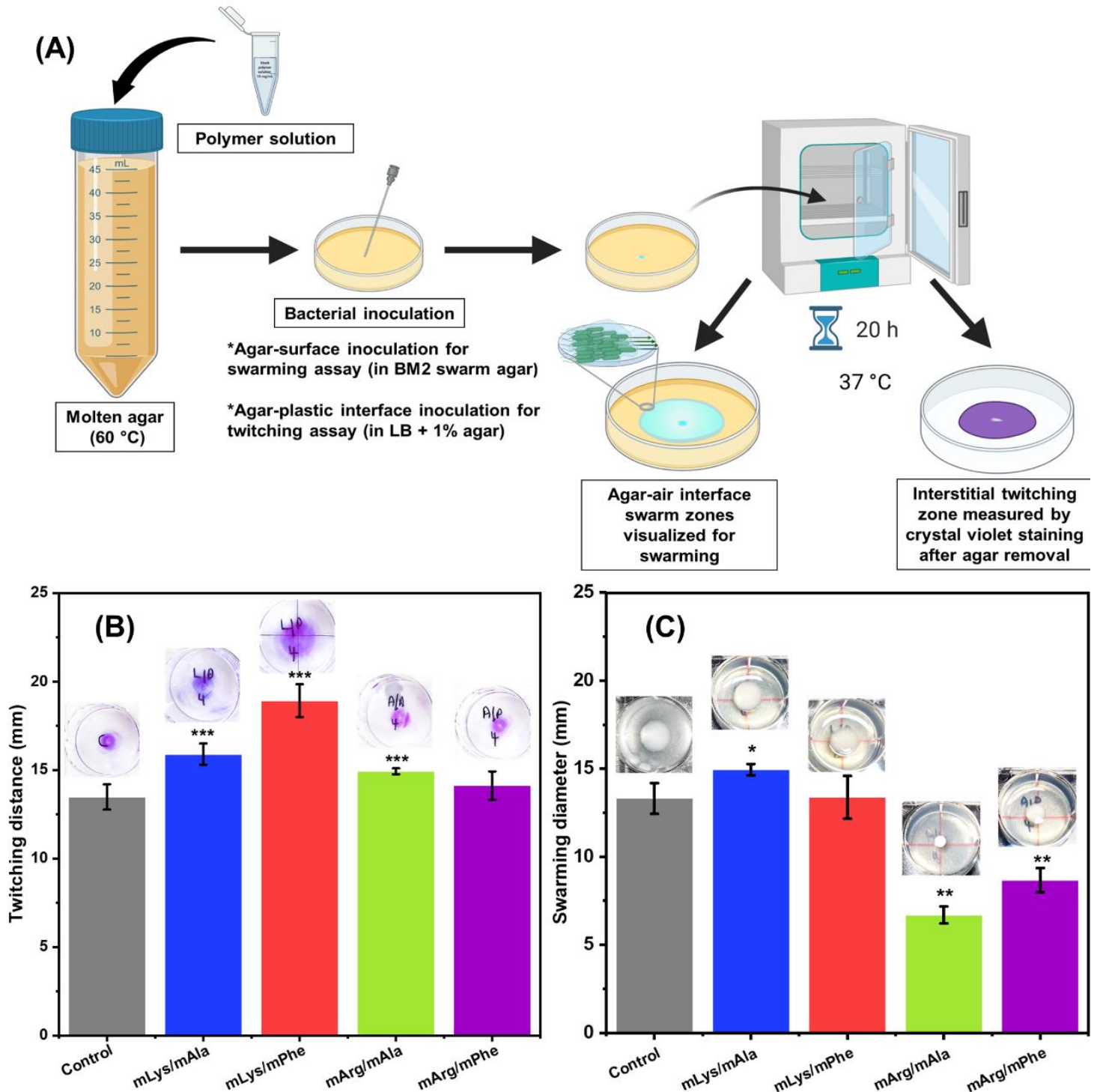

Figure 4. (A) Experimental workflow for the motility assays. (B) Twitching motility of $P$. aeruginosa in presence of polymers. All polymers were added at $4 \mu \mathrm{g} / \mathrm{mL}$ in $\mathrm{LB}$ with $1 \%$ agar and circular twitching zones were measured after $20 \mathrm{~h}$ incubation at $37{ }^{\circ} \mathrm{C}$. $(\mathrm{C})$ Swarming motility of $P$. aeruginosa PAO1 in presence of polymers. All polymers were added at $4 \mu \mathrm{g} / \mathrm{mL}$ in BM $2 \mathrm{swarm}$ plates and circular swarm zones were measured after $16 \mathrm{~h}$ incubation at $37^{\circ} \mathrm{C}$. The twitching or swarming distance of each polymer represents the mean \pm SD of three biological replicates. Statistical significance was determined using one-way ANOVA by comparing swarm diameter of each polymer to control. $(* \mathrm{p}<0.05, * * \mathrm{p}<0.005, * * * \mathrm{p}<0.001)$

Once surface attached, bacteria can either rapidly multiply and secrete extracellular polysaccharides (EPS) to initiate biofilm formation, or they can migrate over the surface to seek better nutrient availability, using mechanisms like twitching or swarming motility. ${ }^{52-53}$ Hence, we also investigated the influence of polymers on bacterial twitching and swarming motilities since they are both social behaviors and have considerable overlap in genes that also regulate the development and maintenance of biofilms. ${ }^{52,54-56}$ Moreover, both twitching and swarming motility have been well studied for $P$. aeruginosa ${ }^{53,57}$ Twitching motility provides a means for bacteria to rapidly colonize surfaces under conditions of high nutrient availability through 'grappling hook' like motions of fibrillar protein structures known as type IV pili. Twitching has been known to play a role in the early stages of biofilm formation and in the disassembly/dispersion of mature biofilms. ${ }^{55}$ Figure $4 \mathrm{~B}$ depicts the influence of the polymers on the twitching motility of $P$. aeruginosa at sub-inhibitory concentrations. Polymers mLys $/ \mathrm{mAla}$ and $\mathrm{mLys} / \mathrm{mPhe}$ showed a notable increase in twitching compared to the control, with $\mathrm{mLys} / \mathrm{mPhe}$ causing about $40 \%$ 
increase in the twitching of $P$. aeruginosa. Polymers with mArg pendant groups had either minimal or no effect on twitching, while polymers with mLys pendant groups caused an increase in twitching motility. These results align with the observations of the adhesion assay, where $\mathrm{mLys} / \mathrm{mPhe}$ had the least bacteria attached to the surface, which could be in part due to the polymer's ability to stimulate twitching in P. aeruginosa. Additionally, twitching motility had a dose-dependent response to concentration for all polymers, and at higher concentrations around $16-32 \mu \mathrm{g} / \mathrm{mL}$, twitching motility was significantly reduced (Figure S3).

Swarming motility is a group translocation involving a coordinated and rapid movement of the bacteria on a semi-solid surface. It involves both the flagella and pili along with the secretion of biosurfactants and is often oppositely regulated to biofilm formation. ${ }^{58}$ Interestingly $\mathrm{mLys} / \mathrm{mPhe}$ did not affect the swarming of $P$. aeruginosa, while $\mathrm{mLys} / \mathrm{mAla}$ caused a slight increase in swarming (Figure $4 \mathrm{C}$ ). However, polymers with $\mathrm{mArg}$ pendant group, namely $\mathrm{mArg} / \mathrm{mAla}$ and $\mathrm{mArg} / \mathrm{mPhe}$, markedly reduced the swarming of $P$. aeruginosa. Increasing polymer concentrations had no significant effect on the swarming up until high concentrations of about 64-128 $\mu \mathrm{g} / \mathrm{mL}$, at which point there was a reduction in swarming diameter, likely due to inhibition of bacterial growth by the polymers (Figure S4). Additionally, swarming motility involves the secretion of biosurfactants that facilitate bacterial motion by reducing the surface tension. The polymers in our study are amphiphilic molecules and may behave like surfactants. To ascertain that the differences in swarming in presence of these polymers were not due to differences in their surface-active properties, we measured the surface tension of the polymer solutions at different concentrations (Figure S5). Up until $32 \mu \mathrm{g} / \mathrm{mL}$, there was no significant decrease in the surface tension of the polymer solutions compared to that of pure water. The surface tension decreased only at much higher concentrations, plateauing close to $5 \mathrm{mg} / \mathrm{mL}$ with a surface tension of about $55 \mathrm{mN} / \mathrm{m}$ for all polymers tested. This suggests that and the differences in swarming of $P$. aeruginosa observed in the presence of $\mathrm{mArg}$ and mLys polymers are not due to differences in their surfactant-like behavior since these polymers do not significantly alter the surface tension of water at concentrations below $500 \mu \mathrm{g} / \mathrm{mL}$.

\section{Hemolysis and cytotoxicity}
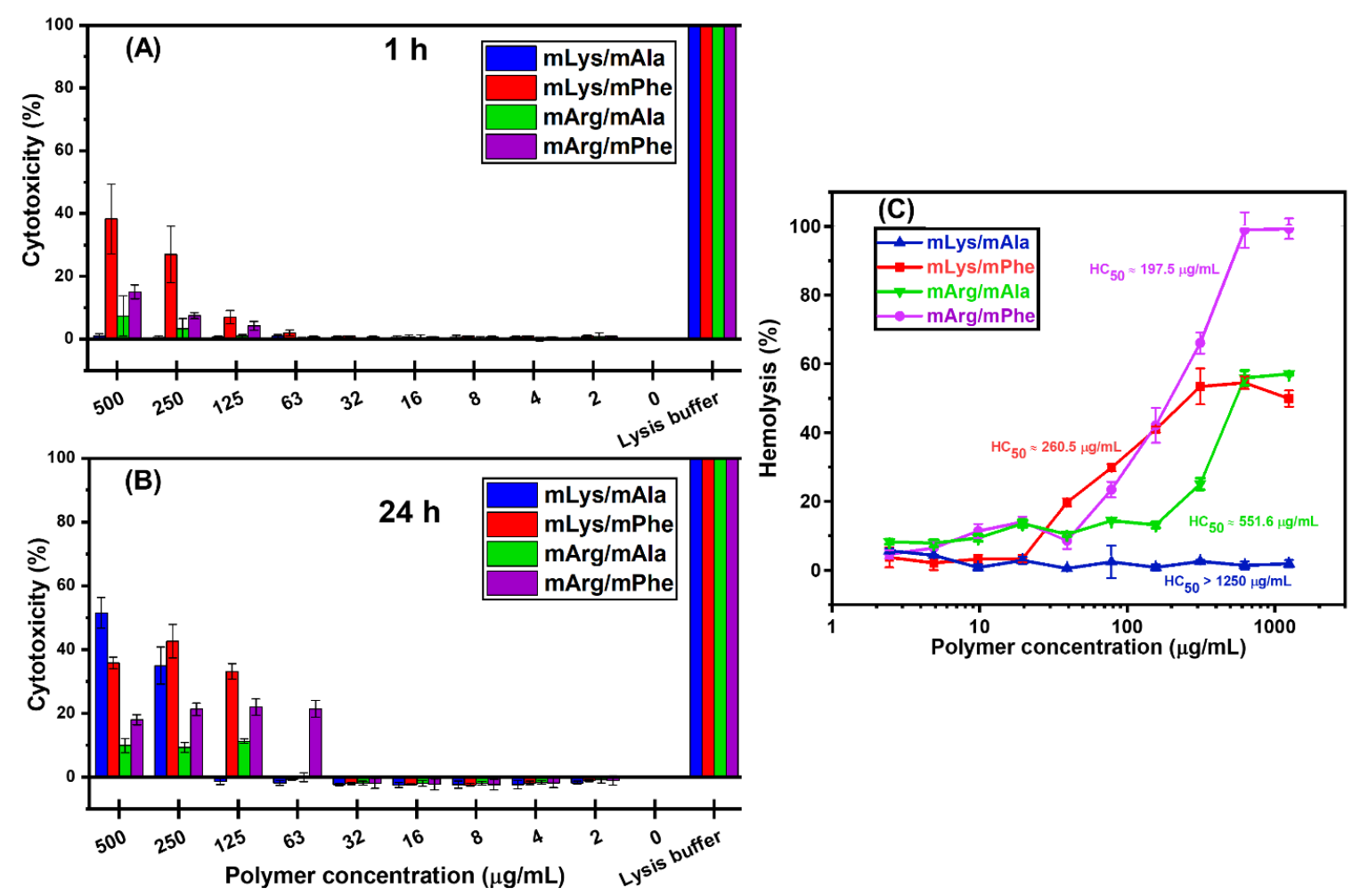

Figure 5. Cytotoxicity to Human Dermal Fibroblasts (HDFs) measured by LDH assay after exposure to polymers for (A) $1 \mathrm{~h}$ (B) $24 \mathrm{~h}$. Percent cytotoxicity relative to controls is represented as mean \pm standard deviation of three biological replicates. (C) Hemolysis of sheep red blood cells in presence of polymers over a broad range of concentrations $(2-1250 \mu \mathrm{g} / \mathrm{mL})$. HC50, polymer concentration to cause $50 \%$ hemolysis is reported in the inset. mLys/mAla caused $<2 \%$ hemolysis for all concentrations tested and so $\mathrm{HC}_{50}$ could not be determined. 
To understand the potential of these polymers as therapeutics, mammalian cell toxicity of the polymers was measured by red blood cell hemolysis (Figure $5 \mathrm{C}$ ) and HDF cytotoxicity (Figure $5 \mathrm{~A}, \mathrm{~B}$ ) at different polymer concentrations. Hemolysis in the presence of the polymers was evaluated by quantifying the relative hemoglobin released at the test concentration compared to $1 \%$ Triton $\mathrm{X}-100$, which was assumed to cause $100 \%$ hemolysis. $\mathrm{HC}_{50}$, defined as the polymer concentration leading to $50 \%$ hemolysis, was determined as shown in Figure $5 \mathrm{C}$, with lower $\mathrm{HC}_{50}$ values indicating higher toxicity to red blood cells. Polymer mLys $/ \mathrm{mAla}$ caused $<2 \%$ hemolysis even at $1250 \mu \mathrm{g} / \mathrm{mL}$, beyond which it began to precipitate out of blood, rendering its $\mathrm{HC}_{50}$ indeterminable. All tested polymers showed significant hemolytic activity only at higher concentrations $\left(\mathrm{HC}_{50}\right.$ for $\mathrm{mLys} / \mathrm{mPhe} \approx$ $260.5 \mu \mathrm{g} / \mathrm{mL}, \mathrm{HC}_{50}$ for $\mathrm{mLys} / \mathrm{mAla}>1250 \mu \mathrm{g} / \mathrm{mL}, \mathrm{HC}_{50}$ for $\mathrm{mArg} / \mathrm{mPhe} \approx 197.5 \mu \mathrm{g} / \mathrm{mL}, \mathrm{HC}_{50}$ for $\mathrm{mArg} / \mathrm{mAla} \approx$ $551.6 \mu \mathrm{g} / \mathrm{mL}$ ) compared to their biofilm-inhibitory concentrations, showing desirable activity within a potential therapeutic window. However, in a very clear trend, polymers with mArg caused significantly more hemolysis than their mLys counterparts, which corroborated our previous reports on a similar polyurethane platform. In accordance with multiple reports in the literature, ${ }^{42,59-61}$ the hemolysis was observed to be significantly higher for polymers with the more hydrophobic mPhe pendant group compared to the polymers with mAla, indicating that even with the same overall cationic charge, increasing hydrophobicity increases the hemolytic activity of the polymers.

To further understand the toxicity posed by the polymers to mammalian cells, we investigated the cytotoxicity of the polymers on HDFs (Figure 5 A, B). HDF cytotoxicity, as measured by the LDH assay, followed a similar trend as hemolysis, with the more hydrophobic mPhe polymers showing higher toxicity than the mAla containing polymers. Interestingly, polymers with mArg showed lower toxicity than the mLys polymers as opposed to the results of the hemolysis assay. Furthermore, the polymers were much less cytotoxic to HDFs than they were to red blood cells, with a maximum cytotoxicity value of $38 \%$ shown by $\mathrm{mLys} / \mathrm{mPhe}$ at $500 \mu \mathrm{g} / \mathrm{mL}$ for $1 \mathrm{~h}$, which remained the same after $24 \mathrm{~h}$ of exposure. The lower toxicity of the polymers can be attributed to HDFs being more resilient to damage than the red blood cells. While mLys/mAla did not show any cytotoxicity at $1 \mathrm{~h}$ for all concentrations tested, it did cause significant cytotoxicity at $24 \mathrm{~h}(51.5 \%$ at $500 \mu \mathrm{g} / \mathrm{mL})$. This indicates that the polymers have a time and concentration dependent cytotoxicity only at concentrations much higher than their biofilm-active concentrations against both HDFs and RBCs, which indicates that their potential as suitable candidates for antibiofilm therapeutics merits further investigation.

\section{CONCLUSIONS}

We report on a class of synthetic, peptidomimetic polyurethanes that disrupt surface established biofilms of a broad spectrum of clinically relevant bacteria without being toxic to mammalian cells. At sub-inhibitory concentrations, these polyurethanes modulate surface interactions of bacteria by influencing motility, such as swarming and twitching, and prevent attachment of the bacteria to surfaces, thus inhibiting the biofilm development. While all the polymers tested had antibiofilm activity, their ability to modulate bacteria-surface interactions was a function of their cationic pendant group. mArg polymers reduced bacterial swarming while mLys polymers enhanced twitching of $P$. aeruginosa at sub-MBIC concentrations. Since the development of resistance in bacteria remains a challenge with antimicrobial and bactericidal agents, the studies described here can serve as the basis for designing polymers that can disperse biofilms without inducing resistance in bacteria. We also urge the antimicrobial polymer community to look beyond the membrane-active bactericidal properties of synthetic cationic polymers. Our results show these polymers may influence bacterial interactions with their environment even at subinhibitory concentrations. While not effective in killing bacteria, the polymers can still be used as a viable strategy to reduce or inhibit the expression of virulence factors that lead to surface attachment, biofilm formation, or surface motility and have the potential to increase severity of an infection. Further investigation can give us insights into the mechanisms by which these polymers influence bacteria-surface interactions, and the role of different chemical functionalities present in the polymers in modulating such interactions. Our findings present a potential strategy not only for the development of biofilm disrupting agents but also for manipulating the bacterial behavior on surfaces with applications in the field of biomaterials, antimicrobial development, bioenergy, and biofouling 


\section{AUTHOR INFORMATION}

\section{Corresponding Author}

Abraham Joy - School of Polymer Science and Polymer Engineering, The University of Akron, Akron, OH 44325, United States; https://orcid.org/0000-0001-7781-3817

Email: abraham@,uakron.edu

\section{Authors}

Apoorva Vishwakarma - School of Polymer Science and Polymer Engineering, The University of Akron, Akron, OH 44325, United States; https://orcid.org/0000-0003-1324-8083

Francis Dang - School of Polymer Science and Polymer Engineering, The University of Akron, Akron, OH 44325, United States; https://orcid.org/0000-0001-6724-5529

Allison Ferrell - School of Polymer Science and Polymer Engineering, The University of Akron, Akron, OH 44325, United States; https://orcid.org/0000-0003-0594-4994

Hazel A. Barton - Department of Biology, The University of Akron, Akron, OH 44325, United States; https://orcid.org/0000-0001-8585-9997

\section{ACKNOWLEDGEMENTS}

The work described herein was funded in part by NSF DMR 1352485. We thank Dr. Chao Peng and Dr. Steven Mankoci for their helpful discussions. We are also grateful to Amal Narayanan and Nicholas Nun for their helpful inputs on the manuscript. The graphical abstract, Fig 1 (A), and Fig 3 (A) were created with BioRender.com.

\section{REFERENCES}

1. Costerton, J. W.; Stewart, P. S.; Greenberg, E. P., Bacterial biofilms: a common cause of persistent infections. Science 1999, 284 (5418), 1318-22.

2. Lebeaux, D.; Ghigo, J.-M.; Beloin, C., Biofilm-Related Infections: Bridging the Gap between Clinical Management and Fundamental Aspects of Recalcitrance toward Antibiotics. Microbiology and Molecular Biology Reviews 2014, 78 (3), 510.

3. Melander, R. J.; Melander, C., Innovative Strategies for Combating Biofilm-Based Infections. In Biofilm-based Healthcare-associated Infections: Volume II, Donelli, G., Ed. Springer International Publishing: Cham, 2015 ; pp 69-91.

4. Bjarnsholt, T., The role of bacterial biofilms in chronic infections. APMIS Suppl 2013, (136), 1-51.

5. James, G. A.; Swogger, E.; Wolcott, R.; Pulcini, E.; Secor, P.; Sestrich, J.; Costerton, J. W.; Stewart, P. S., Biofilms in chronic wounds. Wound Repair Regen 2008, 16 (1), 37-44.

6. Wolcott, R. D.; Rhoads, D. D.; Bennett, M. E.; Wolcott, B. M.; Gogokhia, L.; Costerton, J. W.; Dowd, S. E., Chronic wounds and the medical biofilm paradigm. Journal of Wound Care 2010, 19 (2), 45-53.

7. Wu, H.; Moser, C.; Wang, H. Z.; Hoiby, N.; Song, Z. J., Strategies for combating bacterial biofilm infections. Int J Oral Sci 2015, 7 (1), 1-7.

8. Hall-Stoodley, L.; Costerton, J. W.; Stoodley, P., Bacterial biofilms: from the natural environment to infectious diseases. Nat Rev Microbiol 2004, 2 (2), 95-108.

9. $\quad$ Soares, A.; Roussel, V.; Pestel-Caron, M.; Barreau, M.; Caron, F.; Bouffartigues, E.; Chevalier, S.; Etienne, M., Understanding Ciprofloxacin Failure in Pseudomonas aeruginosa Biofilm: Persister Cells Survive Matrix Disruption. Frontiers in Microbiology 2019, 10 (2603).

10. Bowler, L. L.; Zhanel, G. G.; Ball, T. B.; Saward, L. L., Mature Pseudomonas aeruginosa Biofilms Prevail Compared to Young Biofilms in the Presence of Ceftazidime. Antimicrobial Agents and Chemotherapy 2012,56 (9), 4976.

11. Davies, D., Understanding biofilm resistance to antibacterial agents. Nature Reviews Drug Discovery $2003,2,114$.

12. Ciofu, O.; Rojo-Molinero, E.; Macia, M. D.; Oliver, A., Antibiotic treatment of biofilm infections. APMIS 2017, 125 (4), 304-319.

13. Francolini, I.; Vuotto, C.; Piozzi, A.; Donelli, G., Antifouling and antimicrobial biomaterials: an overview. APMIS 2017, 125 (4), 392-417. 
14. Wolfmeier, H.; Pletzer, D.; Mansour, S. C.; Hancock, R. E. W., New Perspectives in Biofilm Eradication. ACS Infectious Diseases 2018, 4 (2), 93-106.

15. Attinger, C.; Wolcott, R., Clinically Addressing Biofilm in Chronic Wounds. Adv Wound Care (New Rochelle) 2012, $1(3), 127-132$.

16. He, Z.; Wang, Q.; Hu, Y.; Liang, J.; Jiang, Y.; Ma, R.; Tang, Z.; Huang, Z., Use of the quorum sensing inhibitor furanone C-30 to interfere with biofilm formation by Streptococcus mutans and its luxS mutant strain. Int J Antimicrob Agents 2012, 40 (1), 30-5.

17. Amara, N.; Mashiach, R.; Amar, D.; Krief, P.; Spieser, S. A.; Bottomley, M. J.; Aharoni, A.; Meijler, M. M., Covalent inhibition of bacterial quorum sensing. J Am Chem Soc 2009, 131 (30), 10610-9.

18. Abraham, W. R., Going beyond the Control of Quorum-Sensing to Combat Biofilm Infections. Antibiotics (Basel) 2016, 5 (1).

19. Baker, P.; Hill, P. J.; Snarr, B. D.; Alnabelseya, N.; Pestrak, M. J.; Lee, M. J.; Jennings, L. K.; Tam, J.; Melnyk, R. A.; Parsek, M. R.; Sheppard, D. C.; Wozniak, D. J.; Howell, P. L., Exopolysaccharide biosynthetic glycoside hydrolases can be utilized to disrupt and prevent Pseudomonas aeruginosa biofilms. Sci Adv 2016, 2 (5), e1501632.

20. Shah, P. I.; Bush, A.; Canny, G. J.; Colin, A. A.; Fuchs, H. J.; Geddes, D. M.; Johnson, C. A.; Light, M. C.; Scott, S. F.; Tullis, D. E.; et, a., Recombinant human DNase I in cystic fibrosis patients with severe pulmonary disease: a short-term, double-blind study followed by six months open-label treatment. European Respiratory Journal 1995, 8 (6), 954.

21. Itoh, Y.; Wang, X.; Hinnebusch, B. J.; Preston, J. F.; Romeo, T., Depolymerization of $\beta-1,6-$ \&lt;em\&gt;N\&lt;/em\&gt;-Acetyl-\&lt;span class=\&quot;sc\&quot;\&gt;d\&lt;/span\&gt;-Glucosamine Disrupts the Integrity of Diverse Bacterial Biofilms. Journal of Bacteriology 2005, 187 (1), 382.

22. Carson, L.; Gorman, S. P.; Gilmore, B. F., The use of lytic bacteriophages in the prevention and eradication of biofilms of Proteus mirabilis and Escherichia coli. FEMS Immunol Med Microbiol 2010, 59 (3), 447-55.

23. Field, D.; Seisling, N.; Cotter, P. D.; Ross, R. P.; Hill, C., Synergistic Nisin-Polymyxin Combinations for the Control of Pseudomonas Biofilm Formation. Front Microbiol 2016, 7, 1713.

24. Grassi, L.; Maisetta, G.; Esin, S.; Batoni, G., Combination Strategies to Enhance the Efficacy of Antimicrobial Peptides against Bacterial Biofilms. Front Microbiol 2017, 8, 2409.

25. Pletzer, D.; Hancock, R. E. W., Antibiofilm Peptides: Potential as Broad-Spectrum Agents. Journal of Bacteriology 2016, 198 (19), 2572.

26. Pletzer, D.; Coleman, S. R.; Hancock, R. E., Anti-biofilm peptides as a new weapon in antimicrobial warfare. Curr Opin Microbiol 2016, 33, 35-40.

27. Namivandi-Zangeneh, R.; Yang, Y.; Xu, S.; Wong, E. H. H.; Boyer, C., Antibiofilm Platform based on the Combination of Antimicrobial Polymers and Essential Oils. Biomacromolecules 2020, 21 (1), 262-272.

28. Namivandi-Zangeneh, R.; Sadrearhami, Z.; Bagheri, A.; Sauvage-Nguyen, M.; Ho, K. K. K.; Kumar, N.; Wong, E. H. H.; Boyer, C., Nitric Oxide-Loaded Antimicrobial Polymer for the Synergistic Eradication of Bacterial Biofilm. ACS Macro Letters 2018, 7 (5), 592-597.

29. Tan, J. P. K.; Coady, D. J.; Sardon, H.; Yuen, A.; Gao, S.; Lim, S. W.; Liang, Z. C.; Tan, E. W.; Venkataraman, S.; Engler, A. C.; Fevre, M.; Ono, R.; Yang, Y. Y.; Hedrick, J. L., Broad Spectrum Macromolecular Antimicrobials with Biofilm Disruption Capability and In Vivo Efficacy. Adv Healthc Mater 2017, 6 (16).

30. Li, Y.; Fukushima, K.; Coady, D. J.; Engler, A. C.; Liu, S.; Huang, Y.; Cho, J. S.; Guo, Y.; Miller, L. S.; Tan, J. P.; Ee, P. L.; Fan, W.; Yang, Y. Y.; Hedrick, J. L., Broad-spectrum antimicrobial and biofilm-disrupting hydrogels: stereocomplex-driven supramolecular assemblies. Angew Chem Int Ed Engl 2013, 52 (2), 674-8.

31. Overhage, J.; Campisano, A.; Bains, M.; Torfs, E. C. W.; Rehm, B. H. A.; Hancock, R. E. W., Human Host Defense Peptide LL-37 Prevents Bacterial Biofilm Formation. Infection and Immunity 2008, 76 (9), 4176.

32. Singh, P. K.; Parsek, M. R.; Greenberg, E. P.; Welsh, M. J., A component of innate immunity prevents bacterial biofilm development. Nature 2002, 417 (6888), 552-5.

33. de la Fuente-Nunez, C.; Korolik, V.; Bains, M.; Nguyen, U.; Breidenstein, E. B.; Horsman, S.; Lewenza, S.; Burrows, L.; Hancock, R. E., Inhibition of bacterial biofilm formation and swarming motility by a small synthetic cationic peptide. Antimicrob Agents Chemother 2012, 56 (5), 2696-704.

34. de la Fuente-Nunez, C.; Reffuveille, F.; Haney, E. F.; Straus, S. K.; Hancock, R. E., Broad-spectrum anti-biofilm peptide that targets a cellular stress response. PLoS Pathog 2014, 10 (5), e1004152.

35. Haney, E. F.; Brito-Sanchez, Y.; Trimble, M. J.; Mansour, S. C.; Cherkasov, A.; Hancock, R. E. W., Computer-aided Discovery of Peptides that Specifically Attack Bacterial Biofilms. Sci Rep 2018, 8 (1), 1871.

36. Mahlapuu, M.; Hakansson, J.; Ringstad, L.; Bjorn, C., Antimicrobial Peptides: An Emerging Category of Therapeutic Agents. Front Cell Infect Microbiol 2016, 6 (194), 194.

37. Kuroda, K.; Caputo, G. A., Antimicrobial polymers as synthetic mimics of host-defense peptides. WIREs Nanomedicine and Nanobiotechnology 2013, 5 (1), 49-66.

38. Uppu, D. S.; Samaddar, S.; Ghosh, C.; Paramanandham, K.; Shome, B. R.; Haldar, J., Amide side chain amphiphilic polymers disrupt surface established bacterial bio-films and protect mice from chronic Acinetobacter baumannii infection. Biomaterials 2016, 74, 131-43. 
39. Konai, M. M.; Haldar, J., Lysine-Based Small Molecules That Disrupt Biofilms and Kill both Actively Growing Planktonic and Nondividing Stationary Phase Bacteria. ACS Infectious Diseases 2015, 1 (10), 469-478.

40. Sadrearhami, Z.; Yeow, J.; Nguyen, T.-K.; Ho, K. K. K.; Kumar, N.; Boyer, C., Biofilm dispersal using nitric oxide loaded nanoparticles fabricated by photo-PISA: influence of morphology. Chemical Communications 2017, 53 (96), 1289412897.

41. Fischer, D.; Li, Y.; Ahlemeyer, B.; Krieglstein, J.; Kissel, T., In vitro cytotoxicity testing of polycations: influence of polymer structure on cell viability and hemolysis. Biomaterials 2003, 24 (7), 1121-1131.

42. Peng, C.; Vishwakarma, A.; Mankoci, S.; Barton, H. A.; Joy, A., A structure-activity study of antibacterial poly(ester urethane)s with uniform distribution of hydrophobic and cationic groups. Biomacromolecules 2019.

43. Mankoci, S.; Ewing, J.; Dalai, P.; Sahai, N.; Barton, H. A.; Joy, A., Bacterial Membrane Selective Antimicrobial Peptide-Mimetic Polyurethanes: Structure-Property Correlations and Mechanisms of Action. Biomacromolecules 2019, 20 (11), 4096-4106.

44. Mankoci, S.; Kaiser, R. L.; Sahai, N.; Barton, H. A.; Joy, A., Bactericidal Peptidomimetic Polyurethanes with Remarkable Selectivity against Escherichia coli. ACS Biomaterials Science \& Engineering 2017, 3 (10), $2588-2597$.

45. Chamsaz, E. A.; Mankoci, S.; Barton, H. A.; Joy, A., Nontoxic Cationic Coumarin Polyester Coatings Prevent Pseudomonas aeruginosa Biofilm Formation. ACS Appl Mater Interfaces 2017, 9 (8), 6704-6711.

46. de la Fuente-Nunez, C.; Reffuveille, F.; Mansour, S. C.; Reckseidler-Zenteno, S. L.; Hernandez, D.; Brackman, G.; Coenye, T.; Hancock, R. E., D-enantiomeric peptides that eradicate wild-type and multidrug-resistant biofilms and protect against lethal Pseudomonas aeruginosa infections. Chem Biol 2015, 22 (2), 196-205.

47. Peng, C.; Zhang, T.; Ortiz-Ortiz, D. N.; Vishwakarma, A.; Barton, H. A.; Joy, A., Modification of narrow-spectrum peptidomimetic polyurethanes with fatty acid chains confers broad-spectrum antibacterial activity. Polym Int 2019, 68 (7), 1255-1262.

48. Gokhale, S.; Xu, Y.; Joy, A., A library of multifunctional polyesters with "peptide-like" pendant functional groups. Biomacromolecules 2013, 14 (8), 2489-93.

49. Donlan, R. M., Biofilm Formation: A Clinically Relevant Microbiological Process. Clinical Infectious Diseases 2001, 33 (8), 1387-1392.

50. Bos, J.; Zhang, Q.; Vyawahare, S.; Rogers, E.; Rosenberg, S. M.; Austin, R. H., Emergence of antibiotic resistance from multinucleated bacterial filaments. Proceedings of the National Academy of Sciences of the United States of America 2015, 112 (1), 178-183.

51. Suci, P. A.; Mittelman, M. W.; Yu, F. P.; Geesey, G. G., Investigation of ciprofloxacin penetration into Pseudomonas aeruginosa biofilms. Antimicrobial Agents and Chemotherapy 1994, 38 (9), 2125.

52. Verstraeten, N.; Braeken, K.; Debkumari, B.; Fauvart, M.; Fransaer, J.; Vermant, J.; Michiels, J., Living on a surface: swarming and biofilm formation. Trends Microbiol 2008, 16 (10), 496-506.

53. Kohler, T.; Curty, L. K.; Barja, F.; van Delden, C.; Pechere, J. C., Swarming of Pseudomonas aeruginosa is dependent on cell-to-cell signaling and requires flagella and pili. J Bacteriol 2000, 182 (21), 5990-6.

54. Kaiser, D., Bacterial swarming: a re-examination of cell-movement patterns. Curr Biol 2007, 17 (14), R561-70.

55. Mattick, J. S., Type IV pili and twitching motility. Annu Rev Microbiol 2002, 56, 289-314.

56. O'Toole, G. A.; Kolter, R., Flagellar and twitching motility are necessary for Pseudomonas aeruginosa biofilm development. Mol Microbiol 1998, 30 (2), 295-304.

57. Rashid, M. H.; Kornberg, A., Inorganic polyphosphate is needed for swimming, swarming, and twitching motilities of Pseudomonas aeruginosa. Proc Natl Acad Sci U S A 2000, 97 (9), 4885-90.

58. Kearns, D. B., A field guide to bacterial swarming motility. Nat Rev Microbiol 2010, 8 (9), 634-44.

59. Kuroda, K.; Caputo, G. A.; DeGrado, W. F., The Role of Hydrophobicity in the Antimicrobial and Hemolytic Activities of Polymethacrylate Derivatives. Chemistry - A European Journal 2009, 15 (5), 1123-1133.

60. Chin, W.; Zhong, G.; Pu, Q.; Yang, C.; Lou, W.; De Sessions, P. F.; Periaswamy, B.; Lee, A.; Liang, Z. C.; Ding, X.; Gao, S.; Chu, C. W.; Bianco, S.; Bao, C.; Tong, Y. W.; Fan, W.; Wu, M.; Hedrick, J. L.; Yang, Y. Y., A macromolecular approach to eradicate multidrug resistant bacterial infections while mitigating drug resistance onset. Nature Communications 2018, 9 (1), 917.

61. Marie, E.; Sagan, S.; Cribier, S.; Tribet, C., Amphiphilic Macromolecules on Cell Membranes: From Protective Layers to Controlled Permeabilization. The Journal of Membrane Biology 2014, 247 (9), 861-881. 


\section{Supporting Information}

\section{EXPERIMENTAL}

Materials

All materials and solvents were used as received unless described otherwise. Tin(II) 2-ethylhexanoate $\left(\mathrm{Sn}(\mathrm{Oct})_{2}\right), 1 H$-Pyrazole-1-carboxamidine hydrochloride, $N, N$-diethylethanamine, sodium phosphate dibasic, potassium phosphate monobasic, potassium chloride, calcium chloride, iron(II) sulfate, ammonium sulfate, magnesium sulfate, crystal violet, polymyxin B sulfate, and Triton X-100 were purchased from Sigma-Aldrich (St Louis, MO, USA). Di-tert-butyl dicarbonate was purchased from Oakwood Chemical (Estill, SC, USA). Diethanolamine, 3-phenylpropionic acid, 6-aminohexanoic acid, and $\mathrm{D}(+)$-glucose were obtained from Alfa Aesar (Ward Hill, MA, USA). Hexamethylene diisocyanate (HDI) and anhydrous $4 \mathrm{~N} \mathrm{HCl}$ in dioxane were purchased from Acros Organics (Fair Lawn, NJ, USA). Dimethyl sulfoxide (DMSO) and sodium chloride were purchased from BDH Chemicals (Dubai, UAE). Anhydrous methanol, triethylamine, and dimethylformamide (DMF) were purchased from EMD Millipore (Billerica, MA, USA). Thionyl chloride and ciprofloxacin hydrochloride were obtained from TCI Chemicals (Tokyo, Japan). Methylene chloride was dried by distillation after drying with $\mathrm{CaH}_{2}$ and stored over molecular sieves. Mueller Hinton broth (MHB) was purchased from Himedia (Mumbai, India), trypticase soy broth (TSB) was purchased from Becton-Dickinson (Franklin Lakes, NJ, USA) while lysogeny broth (LB) and casamino acids were obtained from Fisher Scientific (Hampton, NH, USA). Agar was added separately to the medium and was purchased from Sigma-Aldrich (St Louis, MO, USA). Viability/cytotoxicity assay kit for staining bacteria was purchased from Biotium (Fremont, CA, USA). Escherichia coli (ATCC 25922), Staphylococcus aureus (ATCC 25923), and Pseudomonas aeruginosa (PAO1) were obtained from the American Type Culture Collection (ATCC). For the hemolysis assay, defibrinated sheep blood was purchased from Hardy Diagnostics (Santa Maria, CA, USA). For mammalian cell culture, penicillin/streptomycin, fetal bovine serum (FBS), and Dulbecco's Modified Eagle Medium (DMEM) were obtained from HyClone (Chicago, IL, USA). The Pierce ${ }^{\mathrm{TM}}$ LDH cytotoxicity assay kit was purchased from Thermo Fisher Scientific (Waltham, MA, USA). Human Dermal Fibroblasts (HDFs) were kindly donated by Dr. Nic Leipzig, University of Akron.

\section{Instrumentation}

${ }^{1} \mathrm{H}$ NMR spectra were acquired using a Varian Mercury $300 \mathrm{MHz}$ spectrometer. The ${ }^{1} \mathrm{H}$ NMR chemical shifts are reported in ppm relative to the residual proton signal in the deuterated solvent. Polymer molecular weight was determined via size exclusion chromatography (SEC) on a TOSOH EcoSec HLC-8320 instrument equipped with an RI detector and two PSS Gram Analytical SEC columns in series with $25 \mathrm{mM} \mathrm{LiBr}$ in DMF as the mobile phase at a flow rate of $0.8 \mathrm{~mL} / \mathrm{min}$. For all the measurements, the column and detector were kept at 50 ${ }^{\circ} \mathrm{C}$, and the molecular weights were estimated using a polystyrene standard curve. BioTek Synergy H1 microplate reader was used for all UV-visible absorbance measurements. Olympus FLUOVIEW FV1000 laser scanning microscope was used to image bacteria and biofilm samples. Ramé-hart contact angle goniometer was used for surface tension experiments. For microbiology experiments, the optical density of bacterial suspension at $600 \mathrm{~nm}$ $\left(\mathrm{OD}_{600}\right)$ was determined using a Hach DR $2800^{\mathrm{TM}}$ spectrophotometer.

\section{Synthesis of monomers and polymers}

The synthesis of all the monomers and polymers was done as previously described. ${ }^{43,}$,7-48 Briefly, the monomeric diols were synthesized by amidation of diethanolamine with methyl esters of desired pendant group and purified by silica gel column chromatography using a mixture of methylene chloride and methanol as the mobile phase. The purified diol monomers were solution polymerized with hexamethylene diisocyanate using tin(II) 2-ethylhexanoate as the catalyst and anhydrous methylene chloride as the solvent for $12 \mathrm{~h}$ at room temperature under $\mathrm{N}_{2}$ flow to yield polymers described in Scheme 1. The polymers were dialyzed against methanol for 24 $\mathrm{h}$ and dried under vacuum overnight and later characterized using ${ }^{1} \mathrm{H}$ NMR and SEC. Deprotection of pendant amine groups was done using $4 \mathrm{~N} \mathrm{HCl}$ in dioxane as previously described. Guanylation of the amine groups was performed as described previously by reacting the polymers with $1 \mathrm{H}$-Pyrazole-1-carboxamidine hydrochloride in presence of triethylamine at $60^{\circ} \mathrm{C}$ for $6 \mathrm{~h}$ in DMF. ${ }^{43}$ 


\section{Determination of Minimum Inhibitory Concentration (MIC) and Minimum Biofilm Inhibitory Concentra- tion (MBIC)}

The broth microdilution method as reported previously was used to measure MIC and MBIC with some modifications. ${ }^{33,44}$ In brief, TSB $(3 \mathrm{~mL})$, was inoculated with an overnight culture of bacteria and incubated at 37 ${ }^{\circ} \mathrm{C}$ with shaking $(200 \mathrm{rpm})$ for $3 \mathrm{~h}$ until the culture reached the mid-log phase. The culture was then diluted into either $2 \times \mathrm{MHB}, 2 \times \mathrm{LB}$, or $2 \times \mathrm{BM} 2$ minimal medium $(124 \mathrm{mM} \mathrm{pH} \mathrm{7}$; potassium phosphate buffer, $4 \mathrm{mM}$ $\mathrm{MgSO}_{4}, 20 \mu \mathrm{M} \mathrm{FeSO}_{4}, 0.8 \%$ (w/v) glucose, $0.5 \%$ (w/v) casamino acids) to yield a working stock of approximately $1 \times 10^{6} \mathrm{CFU} / \mathrm{mL}$. The bacterial stock was added in a 1:1 ratio to serially diluted polymer solutions in sterile polypropylene 96 -well plates. After initial determination $\mathrm{OD}_{600}$, the plates were sealed with breathable membrane and incubated for $16-18 \mathrm{~h}$ at $37{ }^{\circ} \mathrm{C}$ under stationary conditions after which the $\mathrm{OD}_{600}$ was measured again. The lowest concentration that prevented bacterial growth, measured by an increase in $\mathrm{OD}_{600}$ was reported as the MIC. For the determination of MBIC, the bacteria were grown in $2 \times \mathrm{BM} 2$ minimal medium in the presence of polymers. Biofilms were then allowed to form under static conditions for $18 \mathrm{~h}$ at $37^{\circ} \mathrm{C}$. Post incubation, planktonic cells were gently removed by washing with $1 \times$ phosphate-buffered saline (PBS) using a pipette, and the adhered biofilm was stained with $0.1 \%$ crystal violet solution for $20 \mathrm{~min}$. After staining, the excess dye was removed and crystal violet from the biomass was extracted with $100 \%$ ethanol. The absorbance at $595 \mathrm{~nm}$ was measured using a BioTek Synergy H1 microplate reader. Minimum polymer concentration leading to $90 \%$ decrease in biofilm biomass compared to the untreated control was reported as the MBIC. Each experiment was done in triplicate and repeated at least three times.

\section{Biofilm disruption assay and microscopy}

Bacterial stocks of about $1 \times 10^{6} \mathrm{CFU} / \mathrm{mL}$ as described above, were prepared in BM2 minimal medium and glass coverslips of $12 \mathrm{~mm}$ diameter were used as substrates for biofilm formation. These coverslips were sterilized by UV irradiation and placed inside the wells of a sterile 12-well plate. The bacterial suspension $(2 \mathrm{~mL})$ was added to each well and the well plate was incubated at $37^{\circ} \mathrm{C}$ under stationary conditions for $24 \mathrm{~h}$. Post incubation, the biofilm containing coverslips were gently washed with $\mathrm{pH} 7,1 \times \mathrm{PBS}$ to remove planktonic bacteria and then transferred to a sterile 12-well plate. A solution of the polymer in BM2 minimal medium ( $2 \mathrm{~mL})$ at the desired concentration was added to each well and the well plate was incubated again for $24 \mathrm{~h}$ at $37{ }^{\circ} \mathrm{C}$ under stationary conditions. BM2 minimal media $(2 \mathrm{~mL})$ without polymers served as the negative control for the experiment. After $24 \mathrm{~h}$, the coverslips were washed with $1 \times$ PBS to remove planktonic bacteria and stained with Biotium viability/cytotoxicity assay kit according to the manufacturer's instructions. The samples were mounted on a slide and imaged using Olympus FLUOVIEW FV1000 laser scanning microscope with $488 \mathrm{~nm}$ and $559 \mathrm{~nm}$ laser lines. The confocal stacks were processed with FLUOVIEW 3.0 and ImageJ.

\section{Determination of bacterial adhesion in presence of polymers}

Glass coverslips of $12 \mathrm{~mm}$ diameter were used as substrates to study bacterial adhesion. The stock culture of $P$. aeruginosa PAO1 with about $1 \times 10^{6} \mathrm{CFU} / \mathrm{mL}$ in $2 \times \mathrm{BM} 2$ minimal medium served as the inoculant. The bacterial inoculant $(500 \mu \mathrm{L})$ and an aqueous polymer solution of the desired concentration $(500 \mu \mathrm{L})$ were added in 1:1 (v/v) ratio to each well containing a sterile glass coverslip in a 12-well plate. The well plate was incubated at $37{ }^{\circ} \mathrm{C}$ under stationary conditions for $3 \mathrm{~h}$ to allow the cells to adhere to the glass. Post incubation, the glass coverslips were rinsed twice with $1 \times$ PBS to remove unattached cells, stained with Biotium viability/cytotoxicity assay kit, and imaged using Olympus FLUOVIEW FV1000 laser scanning microscope with $488 \mathrm{~nm}$ and $559 \mathrm{~nm}$ laser lines. The attached cells were enumerated using ImageJ for both channels separately and reported as the number of cells attached per unit surface area.

\section{Swarming and twitching motility assays}

Bacterial swarming assays were performed with $P$. aeruginosa PAO1 on BM2 swarming agar plates $(62 \mathrm{mM} ; \mathrm{pH}$ 7 potassium phosphate buffer, $2 \mathrm{mM} \mathrm{MgSO}_{4}, 10 \mu \mathrm{M} \mathrm{FeSO}_{4}, 0.4 \%$ (w/v) glucose, $0.25 \%$ (w/v) casamino acids, $0.5 \%(\mathrm{w} / \mathrm{v})$ agar) in the presence or absence of different concentrations of polymers. The autoclaved agar solution was cooled to $60{ }^{\circ} \mathrm{C}$ and $10 \mathrm{mg} / \mathrm{mL}$ aqueous polymer solution was diluted in it to achieve the desired concentration of the polymer in agar. This mixture was then poured into the wells of 6-well plate and was allowed to cool in a sterile laminar flow hood for $1 \mathrm{~h}$. Then, $1 \mu \mathrm{L}$ of mid-log phase culture of $P$. aeruginosa PAO1 grown in BM2 
minimal medium $\left(\mathrm{OD}_{600}=0.5\right)$ was used to inoculate the agar surface at the center of each well and the well plate was incubated at $37{ }^{\circ} \mathrm{C}$ for $16 \mathrm{~h}$. All resulting circular swarms were analyzed by measuring the swarm diameter using ImageJ and plotted against polymer concentration. Each experiment was performed in triplicate and repeated twice. For studying twitching motility in presence of polymers, $10 \mathrm{~mL}$ of LB supplemented with $1 \%(\mathrm{w} / \mathrm{v})$ agar and the desired polymer concentration was poured into each well of a 6-well plate. A mid-log phase culture of $P$. aeruginosa PAO1 $\left(\mathrm{OD}_{600}=0.5\right)$ was stabbed through the agar, to the plastic interface using a needle. The agar plate was then incubated at $37{ }^{\circ} \mathrm{C}$ for $20 \mathrm{~h}$. Post incubation, the agar was gently removed using a pair of tweezers to expose the twitching zone at the agar-plastic interface. The twitching zone was stained with $0.1 \%$ crystal violet solution and analyzed by measuring the twitching diameters with ImageJ. Each experiment was performed in triplicate and repeated twice.

\section{Hemolysis Assay}

Hemolysis assay was performed using defibrinated sheep red blood cells (RBCs). The cells were centrifuged at $500 \mathrm{~g}$ for $10 \mathrm{~min}$ at $5{ }^{\circ} \mathrm{C}$ and then washed with $\mathrm{pH} 7.4,1 \times$ PBS until no visually observable hemoglobin was present in the supernatant. The RBC suspension was then diluted in a ratio of 1:50 (v/v) in PBS, which was added to serially diluted aqueous polymer solutions in a $1: 1(\mathrm{v} / \mathrm{v})$ ratio and incubated at $37{ }^{\circ} \mathrm{C}$ for $1 \mathrm{~h}$. The wells containing $\mathrm{pH} 7.4,1 \times \mathrm{PBS}$ were used as the negative control and 1\% (w/v) aqueous solution of Triton X-100 was used as the positive control. Post incubation, the well-plate was centrifuged at $500 \mathrm{~g}$ for $10 \mathrm{~min}$ at $4{ }^{\circ} \mathrm{C}$ and the hemoglobin released was quantified at $450 \mathrm{~nm}$ using a BioTek Synergy H1 plate reader. Each sample point was performed in triplicate and percent hemolysis was calculated by using the equation: $\left[\frac{H-H_{0}}{\left(H_{\operatorname{Max}}-H_{0}\right)}\right] \times 100$, where $H$, $H_{0}$ and $H_{\operatorname{Max}}$ represent the absorbance of the sample well, negative control, and positive control at $450 \mathrm{~nm}$, respectively. The percent hemolysis derived from the equation was plotted as a function of polymer concentration. The polymer concentrations which caused $50 \%$ hemolysis relative to the positive control were reported as $\mathrm{HC}_{50}$.

\section{Lactate Dehydrogenase (LDH) Assay for Human Dermal Fibroblast (HDF) cytotoxicity}

The Pierce ${ }^{\mathrm{TM}}$ LDH Cytotoxicity Assay was used to determine the cytotoxicity of the polymers against HDFs as the representative mammalian cells. Cells were cultured in DMEM supplemented with 10\% FBS and $1 \%$ penicillin streptomycin at $37{ }^{\circ} \mathrm{C}$ in $5 \% \mathrm{CO}_{2}$ until reaching about $90 \%$ confluency. Then, the cells were harvested using a $0.25 \%$ trypsin solution and seeded into a 96 -well plate at a cell density of $1 \times 10^{4}$ cells per well. The HDFs were allowed to attach to the wells overnight before adding the polymer solutions. Post polymer addition, the cells were incubated at $37^{\circ} \mathrm{C}$ for $24 \mathrm{~h}$. $50 \mu \mathrm{L}$ medium was pipetted from the wells to determine the cytotoxicity at 1 and $24 \mathrm{~h}$ timepoints according to the instructions provided on the assay kit.

\section{Surface tension measurements}

The surface tension of aqueous polymer solutions at different concentrations was determined using a ramé-hart contact angle goniometer equipped with DROPimage software. Milli-Q Ultrapure water and cetrimonium bromide $(\mathrm{CTAB})$ at $625 \mu \mathrm{g} / \mathrm{mL}$ were used as controls and the surface tension was measured to be $72.7 \pm 1.2$ $\mathrm{mN} / \mathrm{m}$ and $38.0 \pm 0.2 \mathrm{mN} / \mathrm{m}$ respectively. The surface tension of the polymers was reported as mean \pm standard deviation of minimum of five measurements and plotted against concentration. Data was fit using a first-order exponential decay function in the Origin software. 


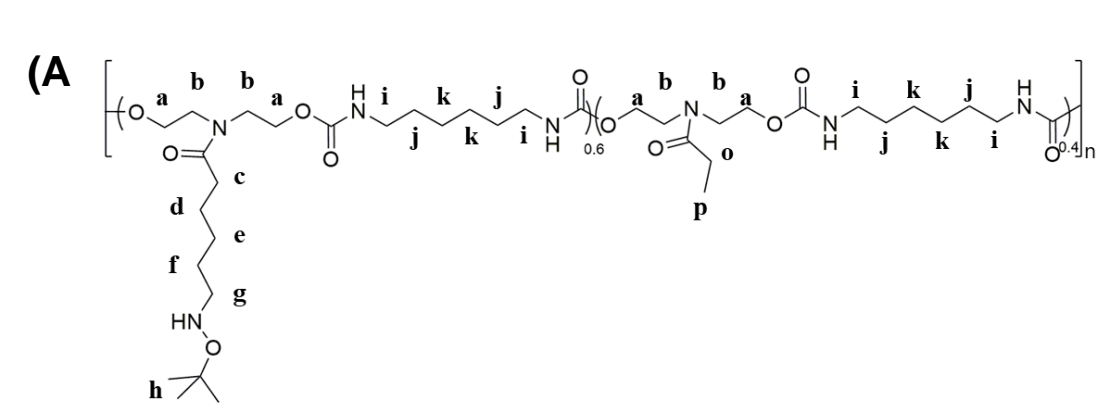

\section{CHLOROFORM-d}

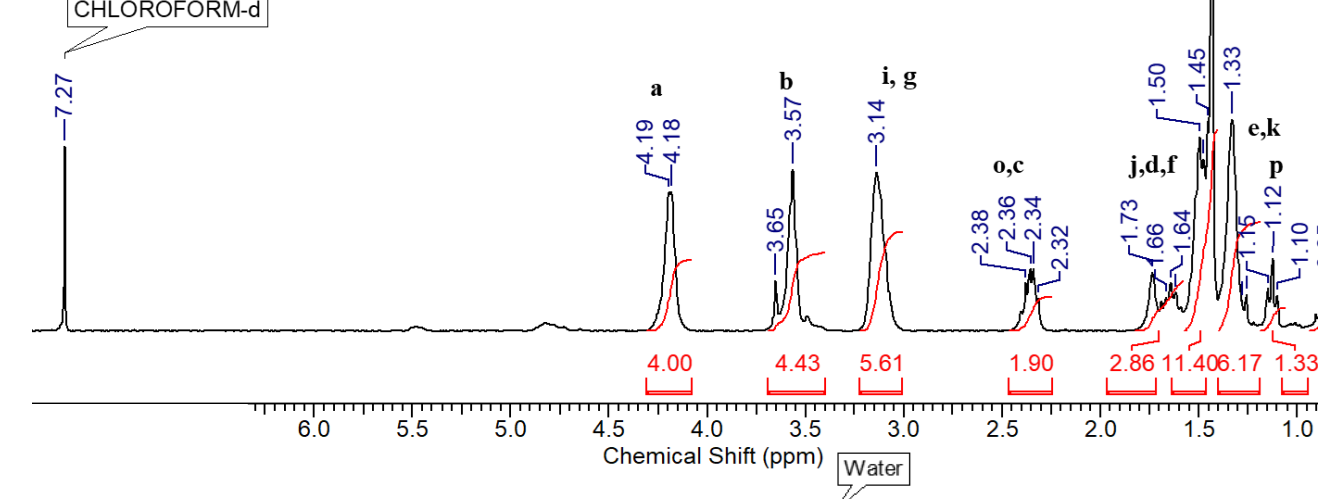

(B
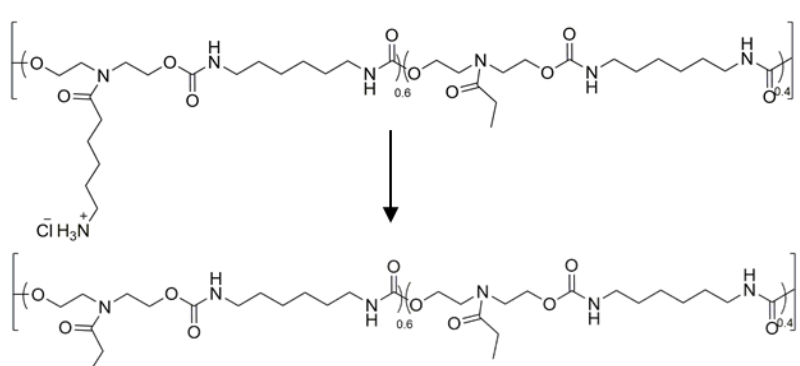

\}

$\mathrm{HN}^{\mathrm{NN}} \stackrel{+}{\mathrm{N}} \mathrm{H}_{3} \overline{\mathrm{Cl}}$
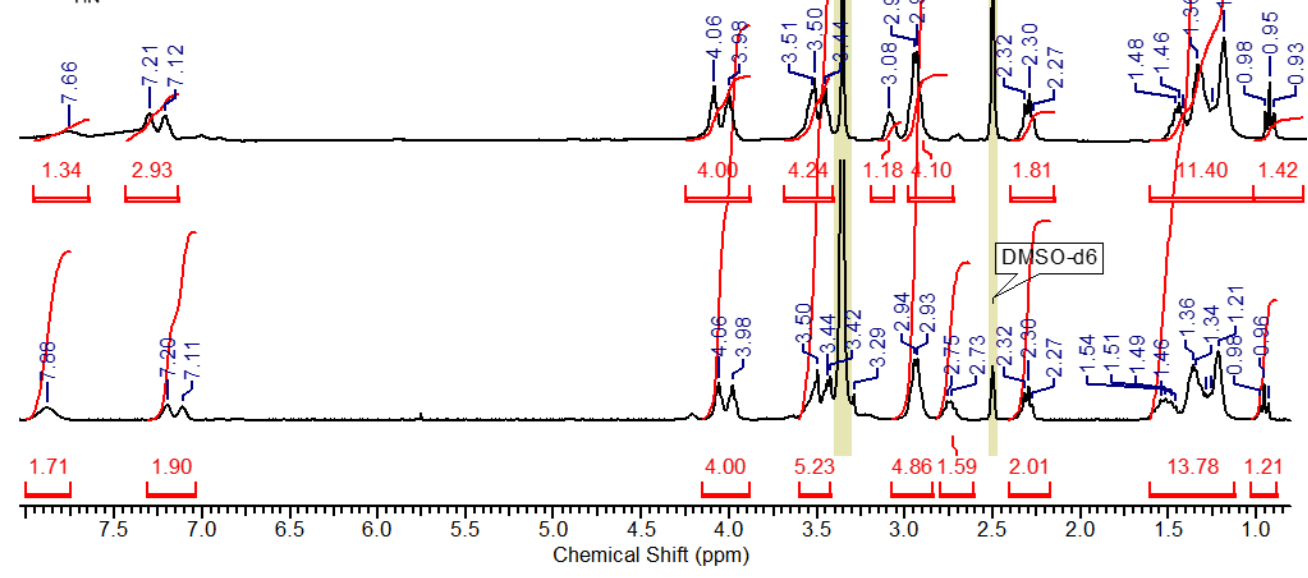

Figure S1. ${ }^{1} \mathrm{H}$ NMR spectrum of (A) Boc-protected mLys/mAla (B) Deprotected mLys/mAla and post polymerization guanylation to obtain $\mathrm{mArg} / \mathrm{mAla}$. 


\section{S. aureus}

(A)
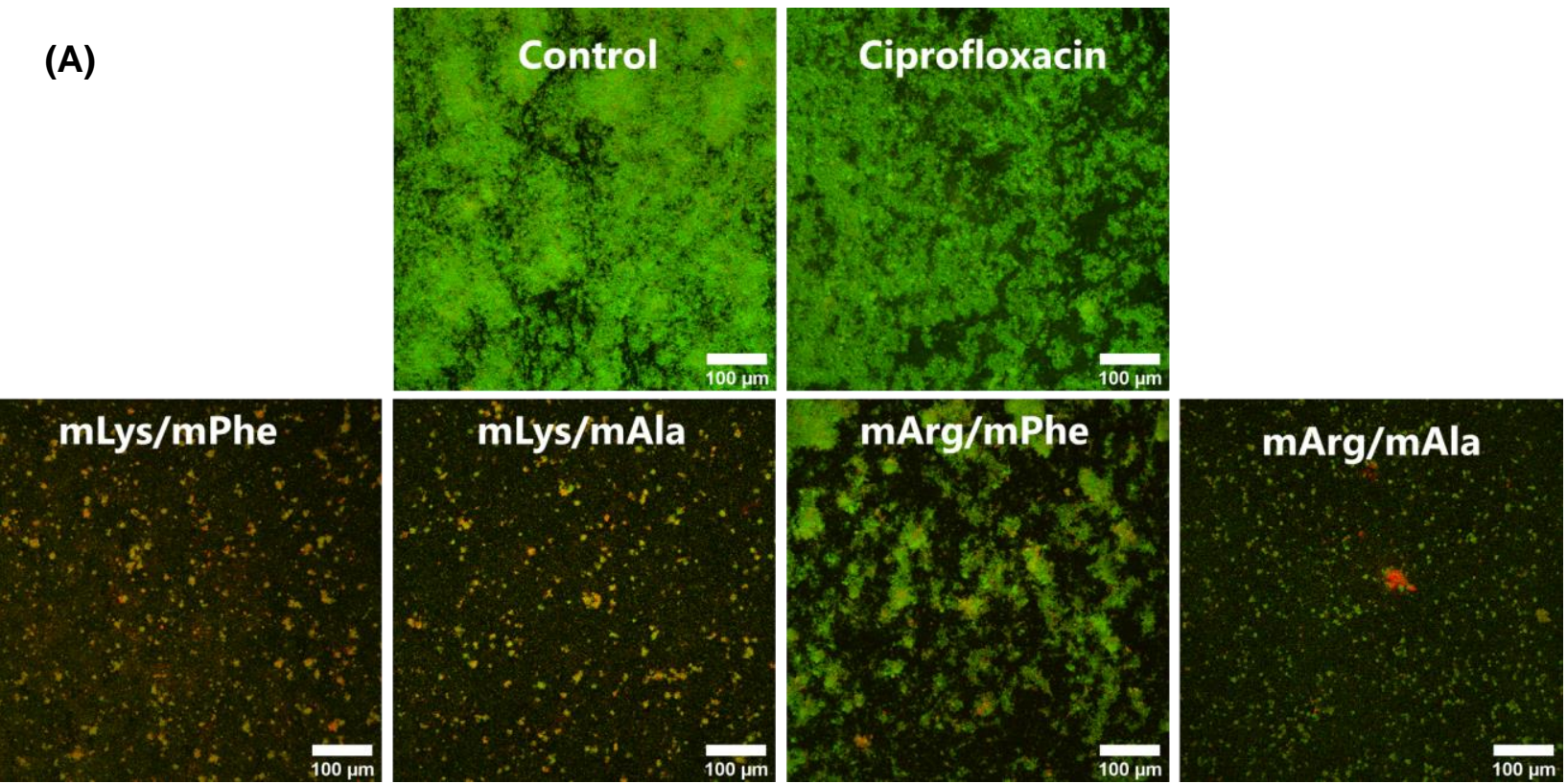

\section{E. coli}

(B)
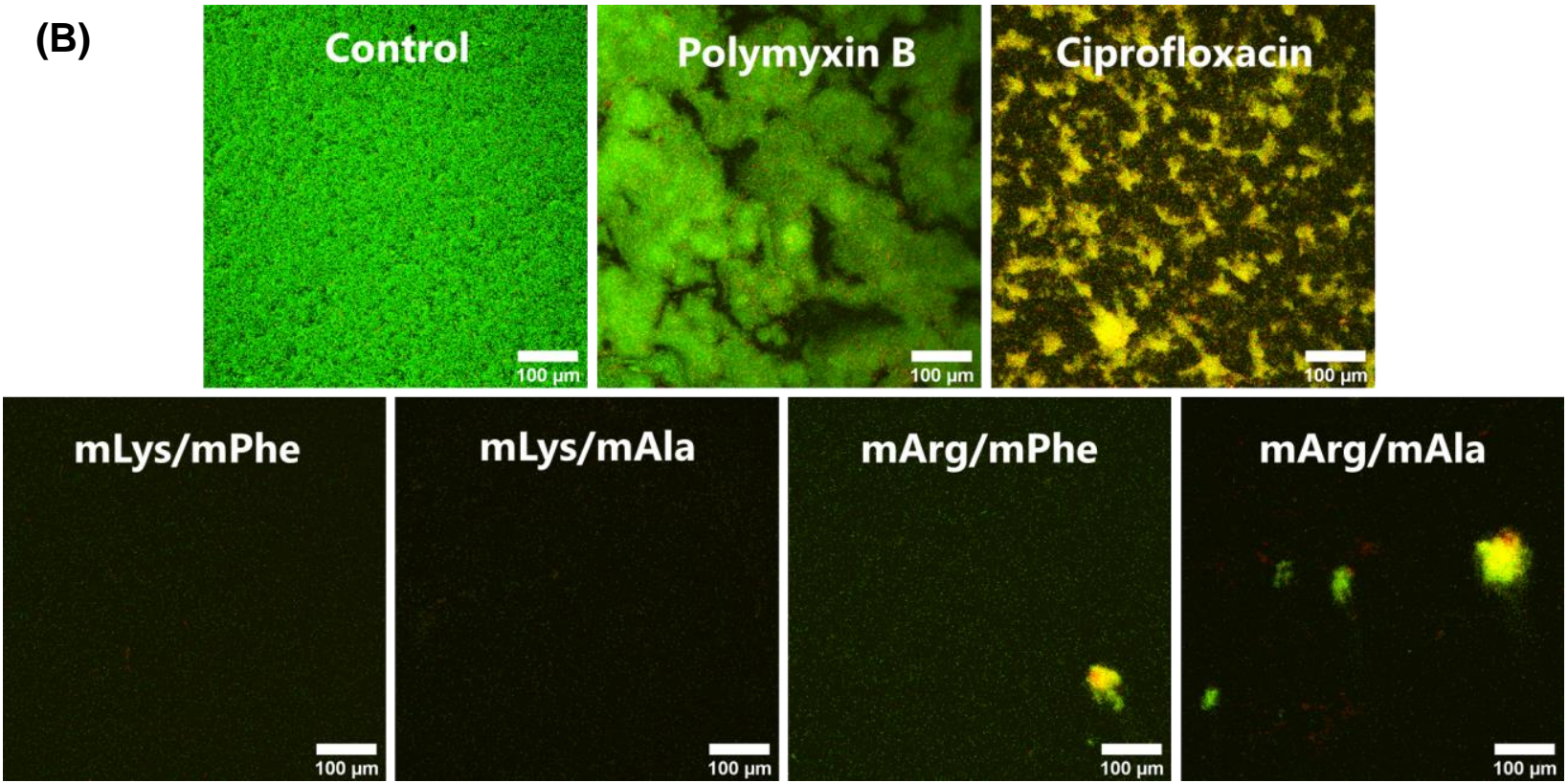

Figure S2. Fluorescence confocal micrographs of preformed S. aureus and E. coli biofilms exposed to antibiotics and polymers. (A) S. aureus biofilms were exposed to ciprofloxacin $(0.8 \mu \mathrm{g} / \mathrm{mL}), \mathrm{mLys} / \mathrm{mPhe}(16 \mu \mathrm{g} / \mathrm{mL}), \mathrm{mLys} / \mathrm{mAla}(32 \mu \mathrm{g} / \mathrm{mL})$, $\mathrm{mArg} / \mathrm{mAla}(16 \mu \mathrm{g} / \mathrm{mL}), \mathrm{mArg} / \mathrm{mPhe}(16 \mu \mathrm{g} / \mathrm{mL})$ for 24 hours. (B) E. coli biofilms were exposed to polymyxin B (1 $\mu \mathrm{g} / \mathrm{mL})$, ciprofloxacin $(1 \mu \mathrm{g} / \mathrm{mL}), \mathrm{mLys} / \mathrm{mPhe}(8 \mu \mathrm{g} / \mathrm{mL}), \mathrm{mLys} / \mathrm{mAla}(32 \mu \mathrm{g} / \mathrm{mL}), \mathrm{mArg} / \mathrm{mAla}(16 \mu \mathrm{g} / \mathrm{mL}), \mathrm{mArg} / \mathrm{mPhe}$ $(16 \mu \mathrm{g} / \mathrm{mL})$ for 24 hours. Biofilms were stained with Live/Dead bacterial viability kit and imaged on a confocal microscope. Permeabilized cells, indicative of cell death fluoresce red, while intact cells, indicative of viable cells fluoresce green. Scale bar represents $100 \mu \mathrm{m}$. 


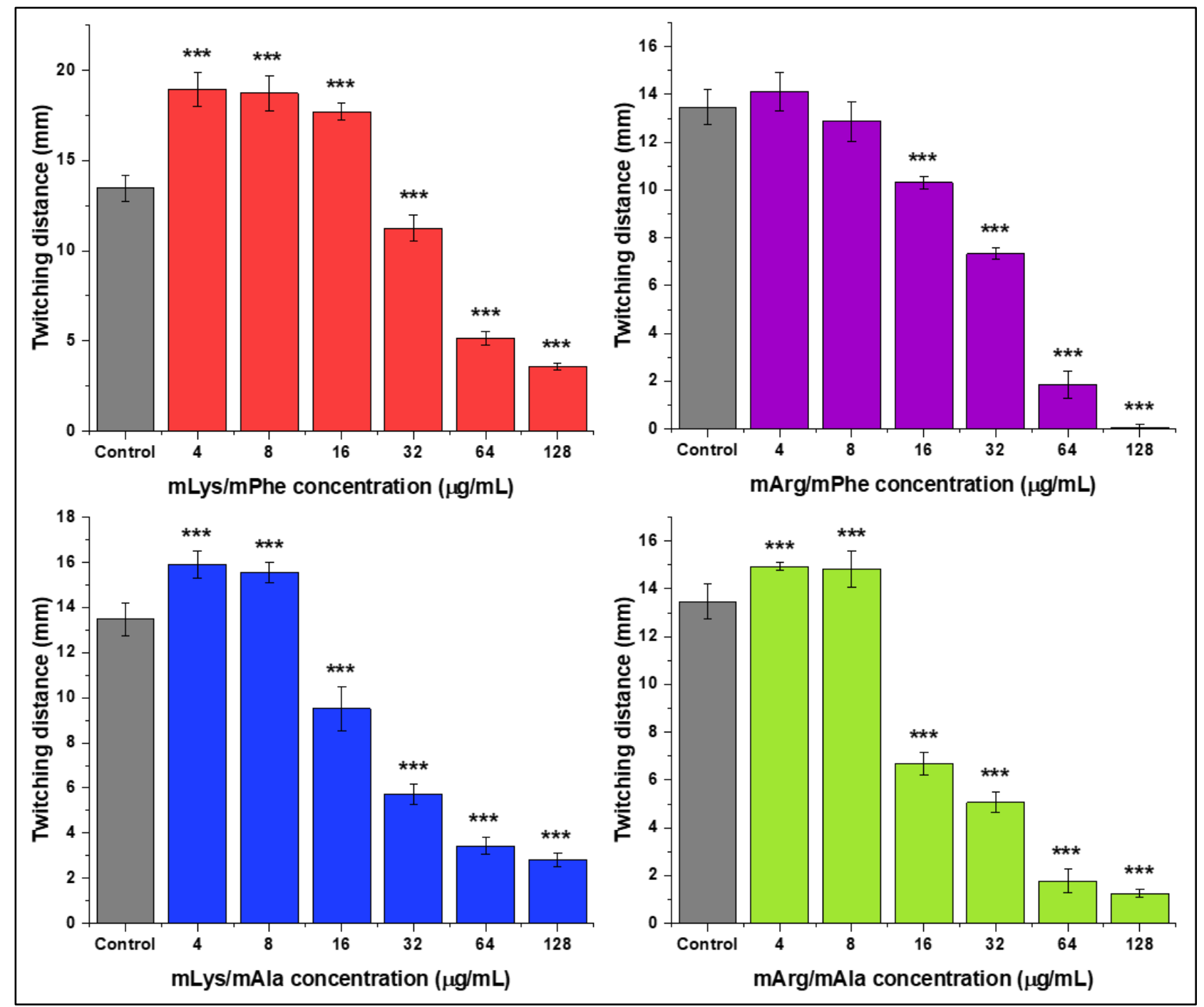

Figure S3 Dependence of polymer concentration on $P$. aeruginosa PAO1 twitching motility. Statistical significance was determined using one-way ANOVA by comparing twitching zones of $P$. aeruginosa in presence of respective polymer concentration to the control. (*** p-value $<0.001)$ 


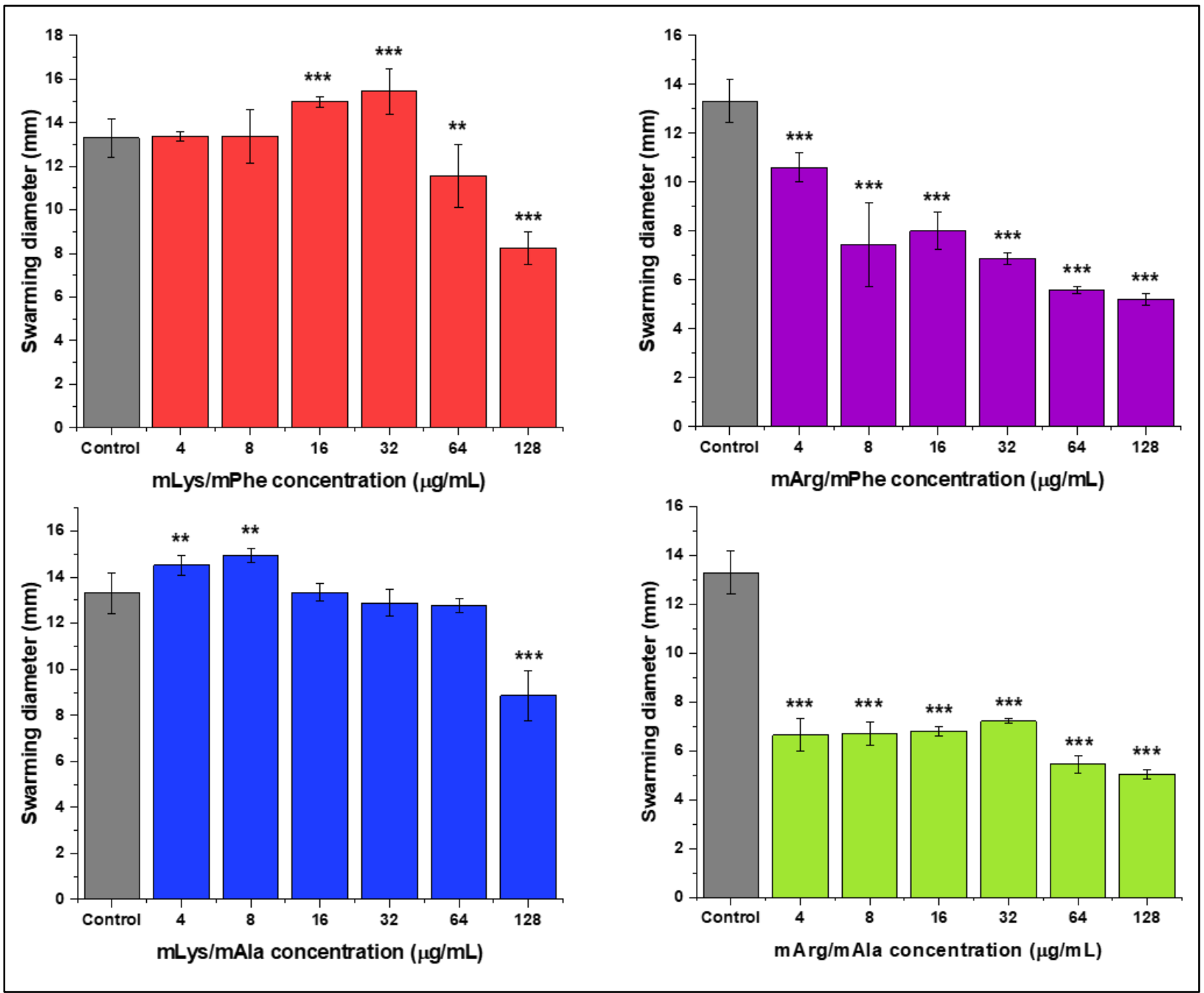

Figure S4. Dependence of polymer concentration on P. aeruginosa PAO1 swarming motility. Statistical significance was determined using one-way ANOVA by comparing the swarm zones of $P$. aeruginosa in presence of each polymer concentration to the control. $(* * \mathrm{p}<0.005, * * * \mathrm{p}$-value $<0.001)$ 


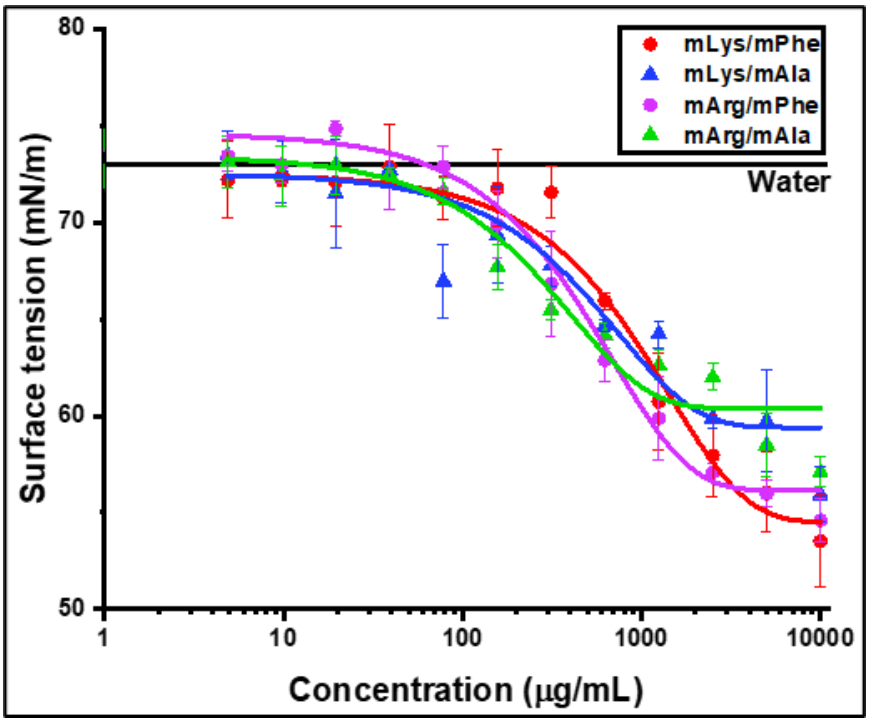

Figure S5. Surface tension as a function of polymer concentration. Each data point represents mean \pm SD of minimum five measurements. Milli-Q Ultrapure water was used as control and the surface tension was measured to be $72.7 \pm 1.2 \mathrm{mN} / \mathrm{m}$. 